Portland State University

PDXScholar

\title{
Future Flooding Impacts on Transportation Infrastructure and Traffic Patterns Resulting from Climate Change
}

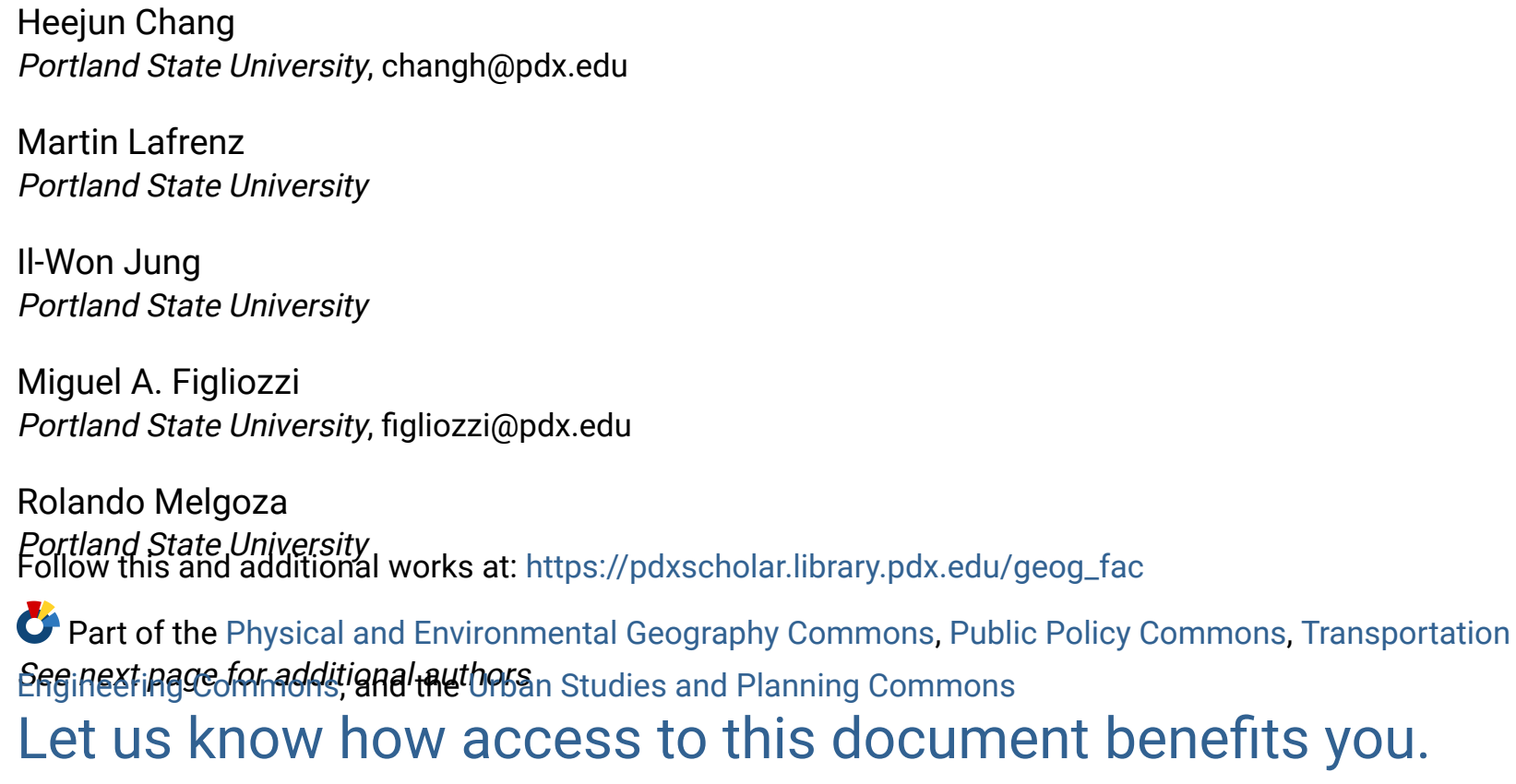

This Report is brought to you for free and open access. It has been accepted for inclusion in Geography Faculty Publications and Presentations by an authorized administrator of PDXScholar. Please contact us if we can make this document more accessible: pdxscholar@pdx.edu. 


\section{Authors}

Heejun Chang, Martin Lafrenz, II-Won Jung, Miguel A. Figliozzi, Rolando Melgoza, David Ruelas, Deena Platman, and Cindy Pederson 

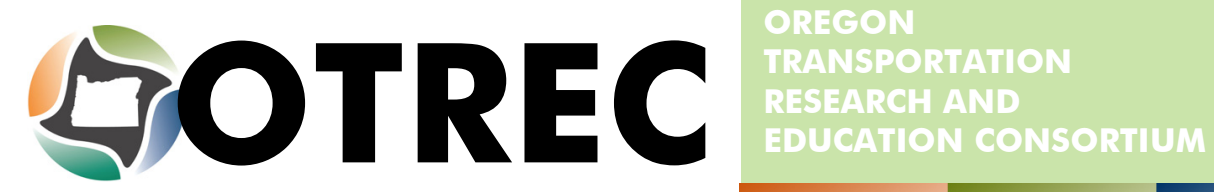

FINAL REPORT

Future Flooding Impacts on Transportation Infrastructure and

Traffic Patterns Resulting from Climate Change

OTREC-RR-1 1-24

November 2011 



\title{
Future Flooding Impacts on Transportation Infrastructure and Traffic Patterns Resulting from Climate Change
}

\author{
Final Report \\ OTREC RR-11-24 \\ by \\ Heejun Chang, Martin Lafrenz, Il-Won Jung \\ Department of Geography, Portland State University \\ Miguel Figliozzi, Rolando Melgoza \\ Department of Civil and Environmental Engineering, Portland State University \\ David Ruelas \\ School of Urban Studies and Planning, Portland State University \\ Deena Platman, Cindy Pederson \\ Portland Metro \\ for \\ Oregon Transportation Research \\ and Education Consortium (OTREC) \\ P.O. Box 751 \\ Portland, OR 97207-0751

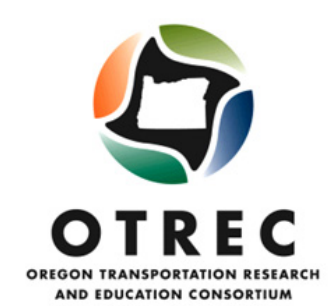

November 2011 



\section{Technical Report Documentation Page}

\begin{tabular}{|l|l|l|}
\hline $\begin{array}{l}\text { 1. Report No. } \\
\text { OTREC-RR-11-24 }\end{array}$ & 2. Government Accession No. \\
\hline
\end{tabular}

4. Title and Subtitle

Future Flooding Impacts on Transportation Infrastructure and Traffic Patterns Resulting from Climate Change

3. Recipient's Catalog No.

5. Report Date

November 2011

6. Performing Organization Code

7. Author(s)

Heejun Chang ${ }^{1}$, Martin Lafrenz ${ }^{1}$, Il-Won Jung ${ }^{1}$, Miguel Figliozzi ${ }^{2}$, Rolando Melgoza ${ }^{2}$, David Ruelas ${ }^{3}$, Deena Platman ${ }^{4}$, Cindy Pederson ${ }^{4}$

9. Performing Organization Name and Address

1 - Department of Geography

2 - Department of Civil and Environmental Engineering

3 - School of Urban Studies and Planning

Portland State University, P.O. Box 751

Portland, OR 97207-0751

4 - Portland Metro

600 NE Grand Ave., Portland, OR 97232-2736

12. Sponsoring Agency Name and Address

Oregon Transportation Research

and Education Consortium (OTREC)

P.O. Box 751

Portland, Oregon 97207

15. Supplementary Notes

\section{Abstract}

This study investigated potential impacts of climate change on travel disruption resulting from road closures in two urban watersheds in the Portland metropolitan area. We used ensemble climate change scenarios, a hydrologic model, stream channel survey, a hydraulic model, and a travel forecast model to develop an integrated impact assessment method. High-resolution climate change scenarios are based on the combinations of two emission scenarios and eight general circulation models. The Precipitation-Runoff Modeling System was calibrated and validated for the period 1988-2006, and simulated for determining the probability of floods from 2020-2049. We surveyed stream cross sections at five road crossings for stream channel geometry and determined floodwater surface elevations using the HEC-RAS model. Four of the surveyed bridges and roadways were lower in elevation than the current 100-year floodwater surface elevation, leading to relatively frequent nuisance flooding. These roadway flooding events will become more frequent under some climate change scenarios in the future, but climate change impacts will depend on local geomorphic conditions. While vehicle miles traveled were not significantly affected by road closure, vehicle-hours delay demonstrated a greater impact from road closures, increasing by 10 percent in the Fanno Creek area. Results indicate that any cost analysis is extremely sensitive to the occurrence of human fatalities or injuries and fairly insensitive to delay costs. In addition, this research presents a comprehensive classification of flooding costs, identifies preventative measures, and makes short- and long-term recommendations. Our research demonstrated the usefulness of the integration of top-down and bottom-up approaches in climate change impact assessment, and the need for spatially explicit modeling and participatory planning in flood management and transportation planning under increasing climate uncertainty.

17. Key Words

climate change; urban flooding; transportation; cost analysis; integrated impact assessment
18. Distribution Statement No restrictions. Copies available from OTREC: www.otrec.us

\begin{tabular}{|l|l|l|l|}
\hline $\begin{array}{l}\text { 19. Security Classification (of this report) } \\
\text { Unclassified }\end{array}$ & $\begin{array}{l}\text { 20. Security Classification (of this page) } \\
\text { Unclassified }\end{array}$ & $\begin{array}{c}21 . \text { No. of Pages } \\
44\end{array}$ & 22. Price \\
\hline
\end{tabular}




\section{ACKNOWLEDGEMENTS}

The authors extend their sincere gratitude to the Oregon Transportation, Research and Education Consortium (OTREC) and Portland State University Research Administration for sponsoring this research. Additional support for Jung was provided by James F. and Marion L. Miller Foundation's post-doctoral fellowship in sustainability. We thank Eric Salathé of the University of Washington for providing downscaled climate change scenarios for the study area. We also appreciate Joe Marek of Clackamas County who provided valuable insights throughout the project period. Thanks also go to Matthew Hampton of Metro for their help and support with the different transportation models and GIS data. The work also benefited from workers within the Washington County and Clackamas County offices who provided valuable resources. Many local volunteers helped with the stream channel survey for our study sites; in particular we wish to thank Brian Wegener, Tualatin Riverkeepers, and Greg Ciannella, Johnson Creek Watershed Council, for helping to organize the volunteer effort. Any omission or error is the sole responsibility of the authors not the sponsoring agencies.

\section{DISCLAIMER}

The contents of this report reflect the views of the authors, who are solely responsible for the facts and the accuracy of the material and information presented herein. This document is disseminated under the sponsorship of the U.S. Department of Transportation University Transportation Centers Program. The U.S. Government assumes no liability for the contents or use thereof. The contents do not necessarily reflect the official views of the U.S. Government. This report does not constitute a standard, specification, or regulation. 


\section{Table of Contents}

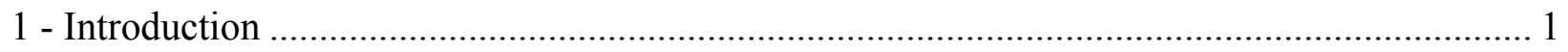

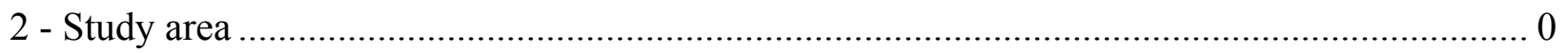

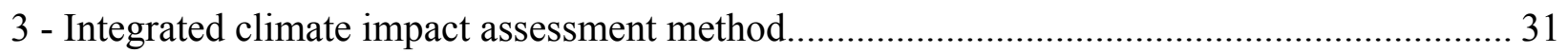

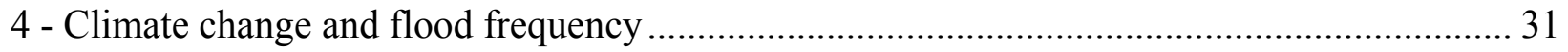

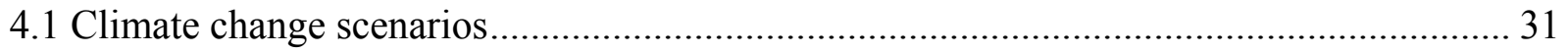

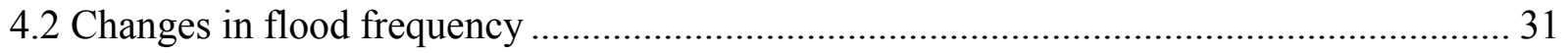

4.3 Change in the probability of road flooding ...................................................................... 31

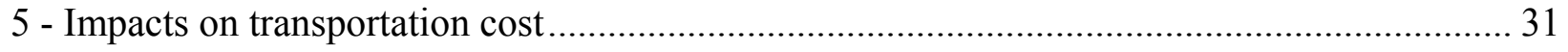

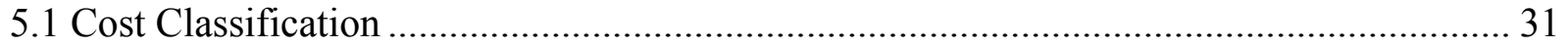

5.1.1 Direct costs to public infrastructure and public agencies ......................................... 31

5.1.2 Direct costs to the population and private property ..................................................... 31

5.1.3 Indirect costs due to delays or reduced accessibility .................................................. 31

5.1.4 Tangible Costs Due to Higher Risk ..................................................................... 31

5.1.5 Intangible Costs Due to Higher Risk ....................................................................... 31

5.2 Cost Estimation and Sensitivity Analysis for Flooding Events ........................................ 31

5.2.1 Direct costs to public infrastructure and public agencies .......................................... 31

5.2.2 Direct costs to the population and private property ................................................... 31

5.2.3 Indirect costs due to delays or reduced accessibility ............................................... 31

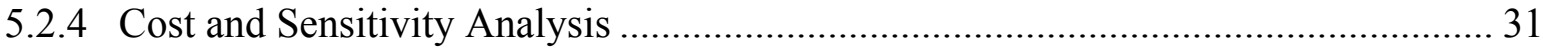

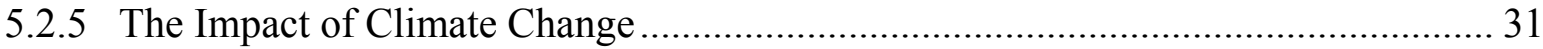

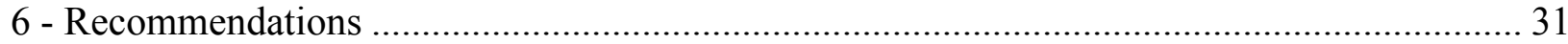

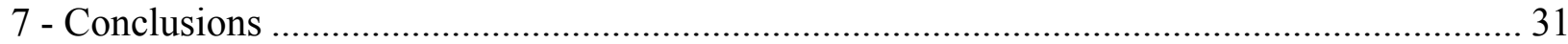

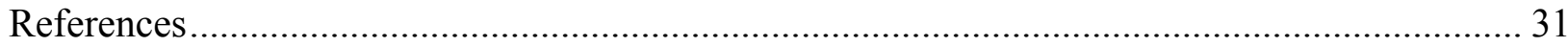




\section{List of Figures}

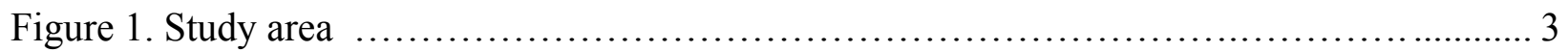

Figure 2. Integrated assessment framework (Source: Chang et al. 2010) …................... 5

Figure 3. Change in future monthly precipitation and temperature from the reference period under 16 climate change scenarios for the Portland metropolitan areas. .................................. 8

Figure 4. Changes in flood flows with recurrence flood intervals for 2, 5, 10, and 25 years under

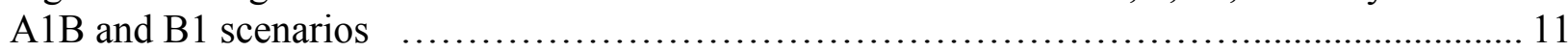

Figure 5. Changes in exceedance days with total days exceeding 2-year recurrence flood interval for each sub-basin.

Figure 6. Stream channel cross-sections with solid horizontal lines indicating the water surface elevations for, from bottom to top, the 2-year, 5-year, 10-year, 25-year, 50-year, and 100-year events.

Figure 7. Changes in travel disruption as a result of road closure, 2005 and 2035 for Fanno Creek and Johnson Creek

Figure 8 - Motorists crossing a flooded roadway (top), Johnson Creek crossing after Jan. 2, 2009 rain

\section{List of Tables}

Table 1. Characteristics of each crossing basin ........................................................ 4

Table 2. Description of Global Climate Models used in this study (Randall et al., 2007) ........ 7

Table 3. PRMS model parameters used for calibration. D : Digital elevation map (10m resolution), L : Land use map, S : Soil map, R : Rosenbrock method. ............................. 9

Table4. Estimated Direct Costs of a Typical Flooding Event ................................... 19

Table 5. Changes in average traffic volume as a result of road closures for 2005 and 2035. .. 20

Table 6. Estimated typical flooding costs with and without fatalities ......................... 23

Table 7. Recommendations for Short and Long Term Response Measures. ..................... 27 


\section{1 - Introduction}

According to the most recent Intergovernmental Panel on Climate Change report (IPCC, 2007), anthropogenic climate change is projected to bring more frequent, heavier winter precipitation and earlier snowmelt in mid-latitude areas. This is due to the fact that warmer air can hold more water vapor, thus accelerating the circulation of water between the atmosphere and land and oceans (Huntington, 2006). As a result of rising intense precipitation and soil moisture content, water tables are likely to increase, leading to more frequent flooding in areas already affected by periodic flooding. This is evidenced by the recent flood events in 2006, 2007 and 2008 in the Pacific Northwest, which severely limited surface transportation and thus disrupted the regional economy. While there is ample need to investigate the vulnerability of regional transportation infrastructure and associated disruption of the transportation systems, very few studies have investigated the potential impacts or adaptation of climate change on the transportation sector (NRC, 2008; Koetse and Rietveld, 2009) other than focusing on reducing greenhouse gas emissions (Black and Sato, 2007; Chapman, 2007).

Of all the possible climate impacts on transportation, the greatest in terms of cost is that of urban flooding (IPCC, 2007). In the last 10 years, there have been four cases when flooding of urban underground rail systems has caused damages costing more than $€ 10 \mathrm{M}$ and numerous cases of lesser damage (Compton et al., 2002). The 1996 flood in the Boston metropolitan area caused $\$ 70$ million in property damage, while also disrupting business and personal travel. In the New York metro area, torrential rainfall in 2004 and 2007 sent water into the subway tunnels because the drainage system could not handle it (Chan, 2007).

To date, only a few studies have examined potential impacts or adaptation of climate change on transportation systems. These studies include regional economic impacts as a result of changing transportation modes in Northern Canada (Lonergan et al., 1993); flood risk mapping for vulnerable roads and the cost of travel disruption in the Boston metropolitan area (Suarez et al., 2005); in the New York metropolitan area (Jacob et al., 2007); in Maryland (Sohn, 2006); and, more comprehensively, along the East Coast (ICF, 2008). These studies, however, used either synthetic climate change scenarios (e.g., hypothetical sea-level rise) or a couple of climate change scenarios, which offered only limited climate impact assessment and quantification of associated uncertainties (Wurbs et al., 2001). Furthermore, they did not model hydrology and geomorphology explicitly at specific intersections of streams and roads, which can vary significantly at a local scale. Only recently have researchers started to investigate potential adaptation of railways in Sweden (Lindgreen et al., 2009) and in the UK (Dobney et al., 2009).

Studies on natural hazard impacts from future climate change have struggled to adequately assess impacts (Soleckie and Rosenzweig, 2001). This is largely due to a lack of data, difficulty in interpreting the existing multidisciplinary data, the complexity of cascading effects resulting from flooding on the regional transportation systems (NRC, 1999), and the focus on attempting to model only extreme events, which are inherently more difficult to predict and model (Pielke and Downton, 2000; Changnon, 2003). With this study, a multidisciplinary team of scientists and urban planners focus on the cumulative effects of a range of flood events, which are likely to increase in frequency as a result of climate change. In addition, we model the shortterm transportation impact from temporary flooding in a few local roadways and estimated costs associated with the delays. 


\section{2 - Study area}

Two creeks - Johnson Creek and Fanno Creek - in the Portland metropolitan area serve as our study sites (Figure 1). These two creeks were chosen because they have historical flow data and exhibit high flooding potential; each also has high road density (Table 1). Daily vehicle miles traveled in Portland increased from 19.4 million to 29.2 million between 1990 and 2007 (Metro, 2009). With different slopes and different degrees of urban development, the hydrological processes of the two watersheds are different. Fanno has highly urbanized and steep slopes, while Johnson Creek has mixed land use with gentle slopes; each serves as a representative for other urban watersheds. Both streams are part of the lower Willamette River watershed. The 42-kilometer Johnson Creek stems from west of the Cascade Range and flows into the Willamette River just north of Elk Rock Island. The 24-kilometer Fanno Creek originates within the Portland city limits and drains into the Tualatin River at river mile 9.3.

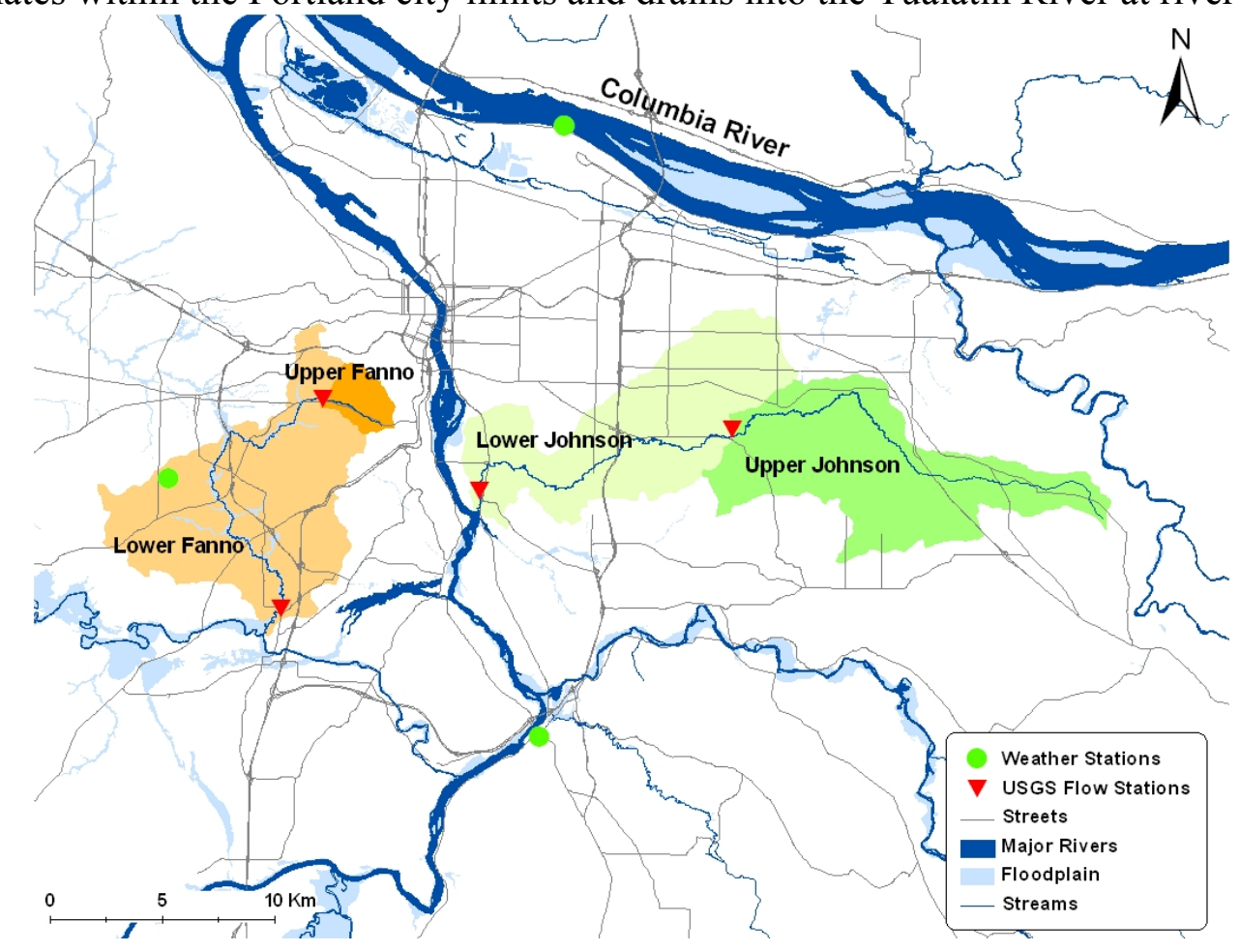

Figure 1. Study area

Largely dominated by the West Coast marine climate, the study area exhibits wet, mild winters and dry, warm summers, with annual precipitation amounts ranging from 1,000 millimeters at the mouth of both creeks to 1,500 millimeters in the headwaters. Precipitation variability is influenced by three- to five-year cycles of ENSO (El Nino/Southern Ocillation) events and the 20- to 30-year cycle of alternating phases of the Pacific Decadal Oscillation. Snowmelt is not a major component of the hydrologic cycle in either watershed, as both are located at relatively low altitudes. Accordingly, streamflow is typically highest during winter months when flooding potentials are high (December to February). Both streams' discharge patterns exhibit the typical behavior of urban streams in the Pacific Northwest, with flashy and 
relatively high flow during winter rainfall periods, and low flows dominated by ground-water discharge during the dry summer (Chang, 2007).

Table 1. Characteristics of each crossing basin

\begin{tabular}{|c|c|c|c|c|c|c|c|c|c|}
\hline \multirow{2}{*}{$\begin{array}{c}\text { Sub- } \\
\text { basin }\end{array}$} & \multirow{2}{*}{$\begin{array}{c}\text { Area } \\
\left(\mathrm{km}^{2}\right)\end{array}$} & \multirow{2}{*}{$\begin{array}{c}\text { Mean } \\
\text { elevation } \\
(\mathrm{m}) \\
\end{array}$} & \multirow{2}{*}{$\begin{array}{c}\text { Mean } \\
\text { slope } \\
\text { (degrees) }\end{array}$} & \multirow{2}{*}{$\begin{array}{c}\text { Road } \\
\text { density } \\
\left(\mathrm{km} / \mathrm{km}^{2}\right)\end{array}$} & \multicolumn{5}{|c|}{ Land use (\%) } \\
\hline & & & & & Urban & Water & Forest & Agricultural & Wetland \\
\hline Oleson & 12.8 & 158 & 7.75 & 12399 & 78.30 & 0.00 & 21.61 & 0.08 & 0.00 \\
\hline Hall & 26.7 & 125 & 5.75 & 11927 & 83.58 & 0.00 & 15.60 & 0.16 & 0.66 \\
\hline Scholls & 30.6 & 118 & 5.31 & 11763 & 84.56 & 0.02 & 13.59 & 1.10 & 0.73 \\
\hline Bell & 117.6 & 134 & 4.57 & 7726 & 59.41 & 0.04 & 18.70 & 20.92 & 0.92 \\
\hline
\end{tabular}

Soil characteristics of the two watersheds are closely associated with bedrock lithology and elevation. The upper portion of Fanno Creek has moderately deep, somewhat poorly drained silt loam soils and significant areas of urban land dominated by impervious surfaces (Green, 1983); the lower portion of the watershed includes deep, somewhat poorly drained and moderately well-drained silt loams (Green, 1982). The upstream areas of Johnson Creek have moderately deep and somewhat poorly drained silt loams, and lower Johnson Creek has more urban land and very deep, well-drained silt and gravelly loam soils (Gerig, 1985). Soil permeability in both creeks reflects elevation gradients.

For all basins, urban land use dominates, comprising more than 50 percent of each basin. In Fanno Creek, urban land use is increasing in downstream basins at the expense of forested areas. Because the upper portion of Johnson Creek is outside of the urban growth boundary, this basin contains a relatively high proportion of agricultural lands. However, a portion of upper Johnson Creek was incorporated into the urban growth boundary in 2002. 


\section{3 - Integrated climate impact assessment method}

Figure 2 exhibits the methodological framework of the integrated assessment of climate change on urban flooding and transportation systems. This framework combines a traditional top-down impact assessment approach with a bottom-up vulnerability analysis. Developing climate change scenarios and downscaling for hydrologic impact assessment follow a traditional top-down approach. Regional stakeholders - the county transportation planner, the regional transportation group, local watershed councils, and community volunteers - were involved at the beginning of the project, informing researchers on the history of flooding and identifying vulnerable transportation nodes. They also provided feedback on our research throughout the project period. While assessments of climate change impacts, adaptation and vulnerability are becoming more sophisticated (Carter et al., 2007), particularly at the regional scale (Knight and Jäger, 2009), to the authors' knowledge, this is the first attempt to apply an integrated assessment approach in the transportation sector.

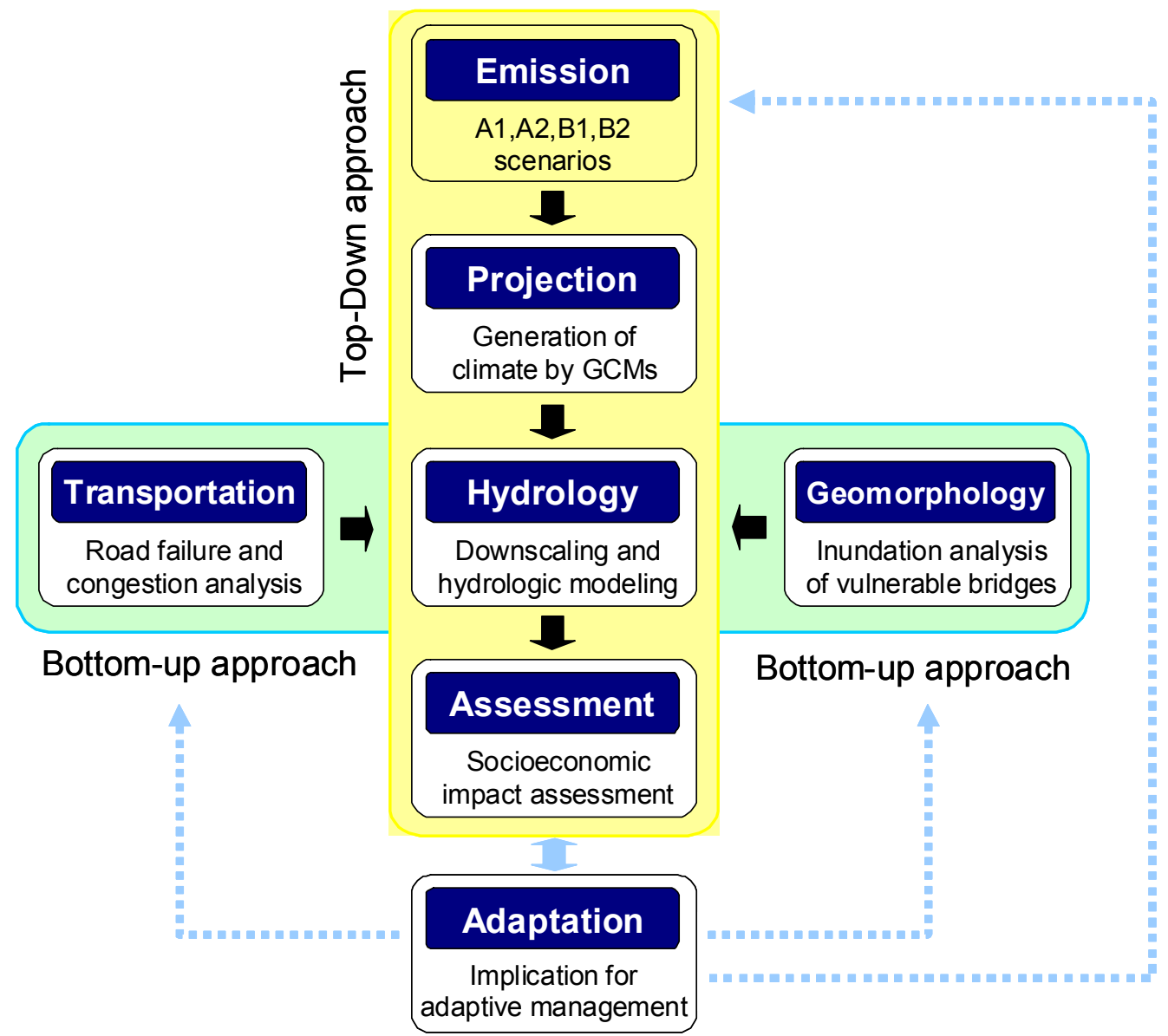

Figure 2. Integrated assessment framework (Source: Chang et al., 2010) 


\section{4 - Climate change and flood frequency}

\subsection{Climate change scenarios}

We used two different sets of climate data for climate modeling. First, observed daily precipitation and temperature from Portland International Airport and Beaverton stations (OCS, 2008) were used for hydrologic modeling. Second, statistically downscaled climate change data at a spatial resolution of 1/16 degree (Salathé et al., 2007) from 16 different climate simulations were used for climate impact assessment. We used the combinations of eight coupled atmosphere ocean global climate models (AOGCMs) and two greenhouse gas emission scenarios to explore uncertainty associated with GCM-model structure and greenhouse gas emission scenarios (Cameron, 2006) (Table 2). The years between 1970 and 1999 serve as a reference period, while the years between 2020 and 2049 serve as a future period representing the years around 2035.

Table 2. Description of Global Climate Models used in this study (Randall et al., 2007)

\begin{tabular}{|c|c|c|c|c|c|}
\hline \multirow{2}{*}{ Model ID } & \multirow{2}{*}{ Acronym } & \multirow{2}{*}{ Country } & \multicolumn{2}{|c|}{ Spatial resolution } & \multirow{2}{*}{ Reference } \\
\hline & & & Atmosphere & Ocean & \\
\hline CCSM3 & CCSM3 & USA & $1.4^{\circ} \times 1.4^{\circ}$ & $1.0^{\circ} \times 1.0^{\circ}$ & Collins et al., 2006 \\
\hline CNRM-CM3 & CNRM & France & $1.9^{\circ} \times 1.9^{\circ}$ & $2.0^{\circ} \times 2.0^{\circ}$ & Terray et al., 1998 \\
\hline ECHAM5/MPI-OM & ECHAM5 & Germany & $1.9^{\circ} \times 1.9^{\circ}$ & $1.5^{\circ} \times 1.5^{\circ}$ & Jungclaus et al., 2005 \\
\hline ECHO-G & ECHO-G & $\begin{array}{l}\text { Germany/ } \\
\text { Korea }\end{array}$ & $3.9^{\circ} \times 3.9^{\circ}$ & $2.8^{\circ} \times 2.8^{\circ}$ & Min et al., 2005 \\
\hline IPSL-CM4 & IPSL & France & $2.5^{\circ} \times 3.75^{\circ}$ & $2.0^{\circ} \times 2.0^{\circ}$ & Marti et al., 2005 \\
\hline MIROC3.2(hires) & MIROC & Japan & $1.1^{\circ} \times 1.1^{\circ}$ & $0.2^{\circ} \times 0.3^{\circ}$ & $\begin{array}{l}\text { K-1 Developers, } \\
2004\end{array}$ \\
\hline PCM & PCM & USA & $2.8^{\circ} \times 2.8^{\circ}$ & $0.7^{\circ} \times 1.1^{\circ}$ & $\begin{array}{l}\text { Washington et al., } \\
2000\end{array}$ \\
\hline UKMO-HadCM3 & UKMO & UK & $2.5^{\circ} \times 3.75^{\circ}$ & $1.25^{\circ} \times 1.25^{\circ}$ & Gordon et al., 2000 \\
\hline
\end{tabular}

The simulated precipitation and temperature data from the downscaled scenarios were compared with observed weather station data. When there were substantial biases in the downscaled data, these biases were corrected using quantile mapping (Wood et al., 2004). The bias-corrected data were then used as inputs to the hydrologic simulation model. Figure 3 shows changes in monthly precipitation and temperature for the study area. As shown in this figure, January and February precipitation amounts are generally projected to increase, while July precipitation is projected to decline regardless of emission scenarios. Temperature is projected to increase overall with higher increases under the A1B emissions scenario. 

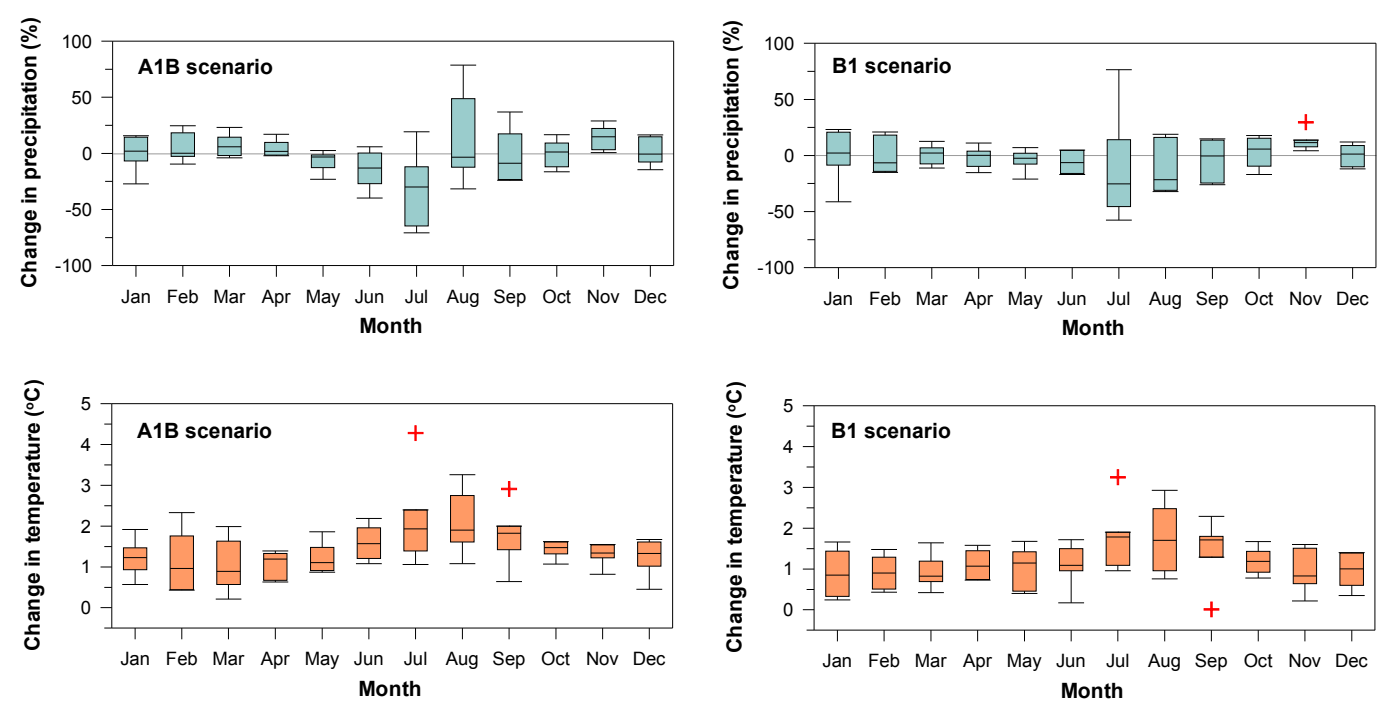

Figure 3. Change in future (2020-2049) monthly precipitation and temperature from the reference period (19701999) under 16 climate change scenarios (eight for A1B, eight for B1) for the Portland metropolitan area. The + sign indicates outliers that fall outside of whisker lengths.

\subsection{Changes in flood frequency}

The U.S. Geological Survey's (USGS) Precipitation Runoff Modeling System (PRMS) simulates runoff changes and resulting changes in flood frequency. This model has been used in climate impact assessment for a range of watersheds around the world (Burlanddo and Rosso, 2002; Dagnachew et al., 2003; Bae et al., 2008). PRMS uses observed daily mean precipitation, and maximum and minimum temperature to simulate daily streamflow. PRMS is a semidistributed, physically-based watershed model, based on hydrologic response units (HRUs) (Leavesley et al., 2002), which is ideal for simulating changes in flow under different environmental scenarios, including climate change. HRUs, assumed to be homogeneous with respect to hydrologic response to climate condition, are partitioned by using a combination of slope, aspect, land use, soil type, and geology.

PRMS model parameters are calibrated focusing on sensitive parameters, which are based on the literature (Laenen and Risley, 1997). Some parameters are directly estimated from the measurable basin characteristics in GIS layers (see Table 3). The remaining parameters (shaded in Table 3) are estimated by Rosenbrock's automatic optimization method (Rosenbrock, 1960). PRMS is calibrated and verified for the four gauged sites for the period between 1988 and 2006. The widely used Nash and Sutcliffe non-dimensional model efficiency criterion (NSE) was used to evaluate the performance of PRMS. The values in excess of 0.6 indicated a satisfactory fit between observed and simulated hydrographs (Wilby and Harris, 2006). We applied the calibrated model for the ungauged cross-section survey sites using the regionalization method (Wagener and Wheater, 2006).

Additionally, we used the web-based GIS application StreamStats, which was developed by USGS (http://water.usgs.gov/osw/streamstats/index.html), to determine the two-year, fiveyear, 10-year, 25-year, 50-year and 100-year discharge values for each of the five surveyed crossing locations. StreamStats uses a regional regression analysis to calculate the discharge for sub-basins and an area-to-discharge relationship to determine the discharge to a user-selected 
location on a stream. The regression equations are specific to a particular region; our study areas fall completely within Oregon flood region $2 \mathrm{~b}$, which includes all basins between the crests of the Cascade and Coast ranges, with a mean basin elevation of less than 3,000 feet (Cooper, 2005).

Table 3. PRMS model parameters used for calibration. D : Digital elevation map (10m resolution), L : Land use map, S : Soil map, R : Rosenbrock method

\begin{tabular}{|c|c|c|c|c|c|}
\hline Parameter & Description & Range & $\begin{array}{l}\text { Initial } \\
\text { values }\end{array}$ & $\begin{array}{l}\text { Calibrated } \\
\text { values }\end{array}$ & Source \\
\hline hru_elev & $\begin{array}{l}\text { Mean elevation for each HRU, in } \\
\text { feet }\end{array}$ & $\begin{array}{l}-300 \sim \\
30000\end{array}$ & - & $117 \sim 602$ & $\mathrm{D}$ \\
\hline hru_slope & $\begin{array}{l}\text { HRU slope in decimal vertical } \\
\text { feet / horizontal feet }\end{array}$ & $0 \sim 10$ & - & $0.01 \sim 0.09$ & $\mathrm{D}$ \\
\hline cov_type & $\begin{array}{l}\text { Cover type }(0=\text { bare, } 1=\text { grasses, } \\
2=\text { shrubs, } 3=\text { trees })\end{array}$ & $0 \sim 3$ & - & $0 \sim 3$ & $\mathrm{~L}$ \\
\hline $\begin{array}{l}\text { covden } \\
\text { sum }\end{array}$ & Summer vegetation cover density & $0 \sim 1$ & - & $0.01 \sim 0.9$ & $\mathrm{~L}$ \\
\hline $\begin{array}{l}\text { covden } \\
\text { win }\end{array}$ & Winter vegetation cover density & $0 \sim 1$ & - & $0.01 \sim 0.8$ & $\mathrm{~L}$ \\
\hline $\begin{array}{l}\text { wrain } \\
\text { intcp }\end{array}$ & $\begin{array}{l}\text { Winter rain interception storage } \\
\text { capacity, in inch }\end{array}$ & $0 \sim 5$ & - & $0.001 \sim 0.05$ & $\mathrm{~L}$ \\
\hline srain_intcp & $\begin{array}{l}\text { Summer rain interception storage } \\
\text { capacity, in inch }\end{array}$ & $0 \sim 5$ & - & $0.001 \sim 0.05$ & $\mathrm{~L}$ \\
\hline $\begin{array}{l}\text { snow_ } \\
\text { intcp }\end{array}$ & $\begin{array}{l}\text { Winter snow interception storage } \\
\text { capacity, in inch }\end{array}$ & $0 \sim 5$ & - & $0.001 \sim 0.1$ & $\mathrm{~L}$ \\
\hline $\begin{array}{l}\text { hru_- } \\
\text { percent_- } \\
\text { imperv }\end{array}$ & $\begin{array}{l}\text { HRU impervious area, in decimal } \\
\text { percent }\end{array}$ & $0 \sim 1$ & - & $0.1 \sim 0.6$ & $\mathrm{~L}$ \\
\hline soil_type & $\begin{array}{l}\text { HRU soil type }(1=\text { sand, } 2= \\
\text { loam, } 3=\text { clay })\end{array}$ & $1 \sim 3$ & - & $1 \sim 3$ & $\mathrm{~S}$ \\
\hline $\begin{array}{l}\text { soil_moist_ } \\
\text { max }\end{array}$ & $\begin{array}{l}\text { Maximum available water holding } \\
\text { capacity in soil profile, in inch }\end{array}$ & $0 \sim 20$ & - & $5 \sim 9$ & $\mathrm{~S}$ \\
\hline _max $_{\max }$ rechr & $\begin{array}{l}\text { Maximum available water holding } \\
\text { capacity for soil recharge zone, in } \\
\text { inch }\end{array}$ & $0 \sim 10$ & - & $1 \sim 2$ & $\mathrm{~S}$ \\
\hline $\begin{array}{l}\text { hamon } \\
\text { coef }\end{array}$ & $\begin{array}{ll}\text { Hamon } & \text { evapotranspiration } \\
\text { coefficient }\end{array}$ & $\begin{array}{c}0.004 \sim \\
0.008\end{array}$ & 0.0055 & $\begin{array}{c}0.004 \sim \\
0.008\end{array}$ & $\mathrm{R}$ \\
\hline $\begin{array}{l}\text { soil2gw } \\
\max \end{array}$ & $\begin{array}{l}\text { Maximum rate of soil water } \\
\text { excess moving to ground water }\end{array}$ & $0.0-5.0$ & 0.15 & $0.12-0.15$ & $\mathrm{R}$ \\
\hline smidx_coef & $\begin{array}{l}\text { Coefficient in nonlinear surface } \\
\text { runoff contributing area algorithm }\end{array}$ & $\begin{array}{l}0.0001- \\
1.0000\end{array}$ & 0.01 & 0.001 & $\mathrm{R}$ \\
\hline smidx_exp & $\begin{array}{l}\text { Exponent in nonlinear surface } \\
\text { runoff contribution area algorithm }\end{array}$ & $0.2-0.8$ & 0.3 & $0.20-0.21$ & $\mathrm{R}$ \\
\hline ssrcoef_sq & $\begin{array}{l}\text { Coefficient to route subsurface } \\
\text { storage to streamflow }\end{array}$ & $0.0-1.0$ & 0.1 & $0.05-0.44$ & $\mathrm{R}$ \\
\hline ssrcoef_lin & $\begin{array}{l}\text { Coefficient to route subsurface } \\
\text { storage to streamflow }\end{array}$ & $0.0-1.0$ & 0.1 & 0.0001 & $\mathrm{R}$ \\
\hline $\begin{array}{l}\text { ssr2gw_- } \\
\text { exp }\end{array}$ & $\begin{array}{l}\text { Coefficient to route water from } \\
\text { subsurface to groundwater }\end{array}$ & $0.0-3.0$ & 1.0 & $0.5-3.0$ & $\mathrm{R}$ \\
\hline
\end{tabular}




\begin{tabular}{|l|l|c|c|c|c|}
\hline $\begin{array}{l}\text { ssr2gw } \\
\text { rate }\end{array}$ & $\begin{array}{l}\text { Coefficient to route water from } \\
\text { subsurface to groundwater }\end{array}$ & $0.0-1.0$ & 0.1 & $0.006-0.02$ & $\mathrm{R}$ \\
\hline $\begin{array}{l}\text { gwflow_ } \\
\text { coef }\end{array}$ & Ground-water routing coefficient & $\begin{array}{c}0.000- \\
1.000\end{array}$ & 0.015 & $0.003-0.07$ & $\mathrm{R}$ \\
\hline
\end{tabular}

We estimated the changes in flood frequency with different recurrence intervals by using the PeakFQ program developed by the USGS (Flynn et al., 2006). The PeakFQ provides estimates of instantaneous annual-maximum peak flows with recurrence intervals of two, five, $10,25,50$, and 100 years based on flood-frequency analyses recommended in Bulletin 17B (IACWD, 1982). With this method, we constructed annual peak flows using simulated daily discharge values by the PRMS model for 1970-1999 and for 2020-2049 at the four study areas.

Recurrence flood flows for the reference period demonstrates that the results simulated by PRMS using the downscaled climate simulations agree well with estimated flood flows from the USGS StreamStats. In particular, the below-25-year recurrence flood flows have the best agreement with the USGS StreamStats results. Most inundated flood flows (dashed lines) occur between the 10-year and 25-year recurrence flood flows, except at the Scholls Ferry site. The over-50-year recurrence flood flows are highly affected by the different GCM structures; however, the emission scenario impacts reveal relatively fewer differences than the GCM structure.

The recurrence flood flows for 2020-2049 represent the differences in the direction of change according to recurrence interval and the GCM simulations. As shown in Figure 4, ensemble-averaged two-year, five-year and 10-year recurrence flood flows at all sites increase, while the ensemble-mean flood flows for 25-year recurrence interval does not change under the A1B scenario. However, they do increase under some climate change scenarios, suggesting that the magnitude and directions of change in the higher flood flows in the study areas are more affected by GCM structures than the emission scenarios. 

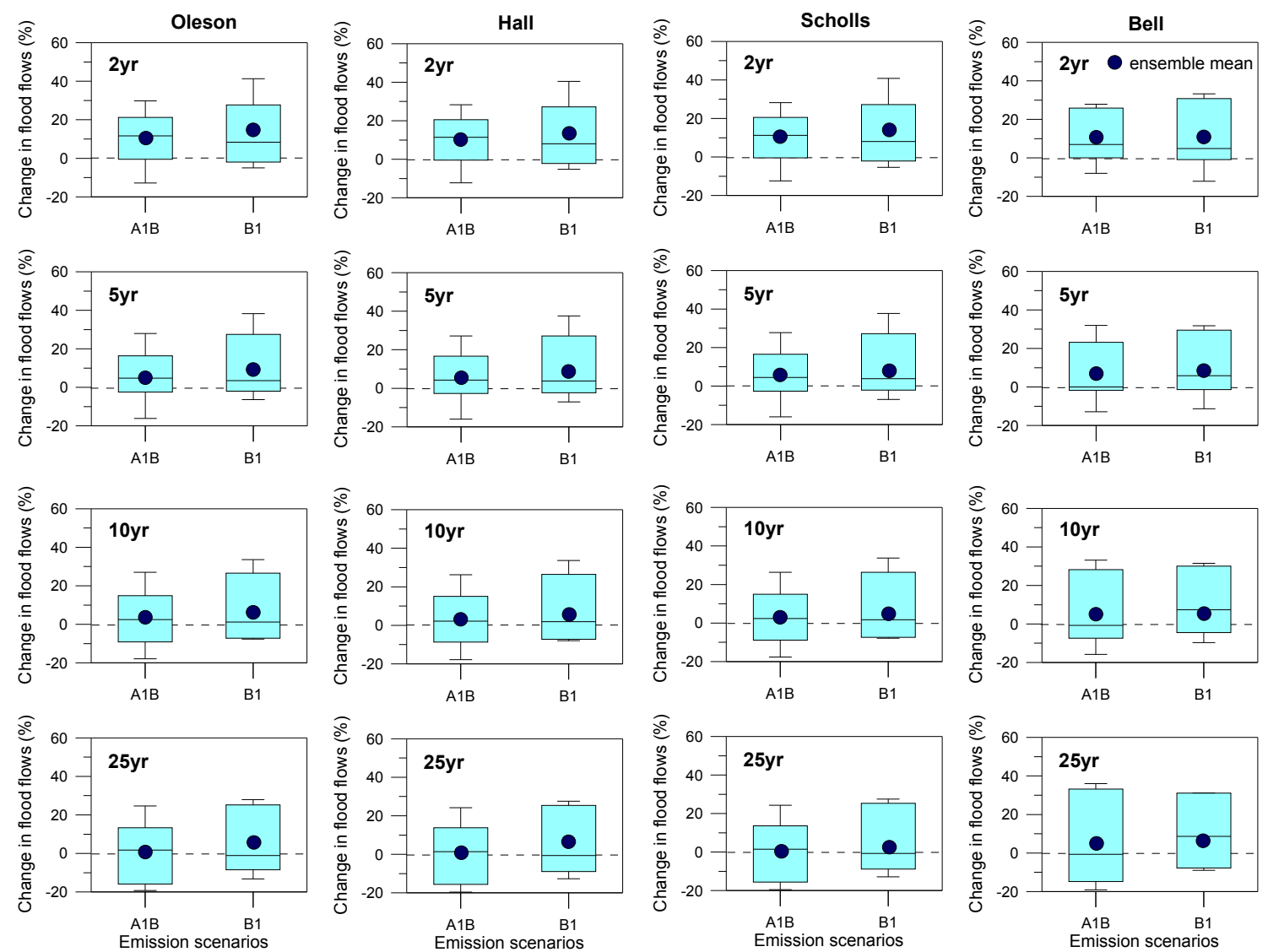

Figure 4. Changes in flood flows with recurrence flood intervals for two, five, 10 and 25 years under A1B and B1 scenarios

Figure 5 shows the change in days that exceeded the two-year recurrence flood flows. These values show approximately 30 to 60 days for the reference period and 30 to 80 days for 2020-2049. Although the mean of the exceedance days increases at all sites, the GCMs and the emission scenarios remain as the main source of uncertainty, with higher uncertainty associated with the choice of GCM. Our finding is consistent with those from previous studies. For example, the largest source of uncertainty was the GCM structure in UK catchments (Wilby and Harris, 2006; Kay et al., 2009). Exceedance probability of the inundated discharge for ensemble mean does not change remarkably (Table 5). 


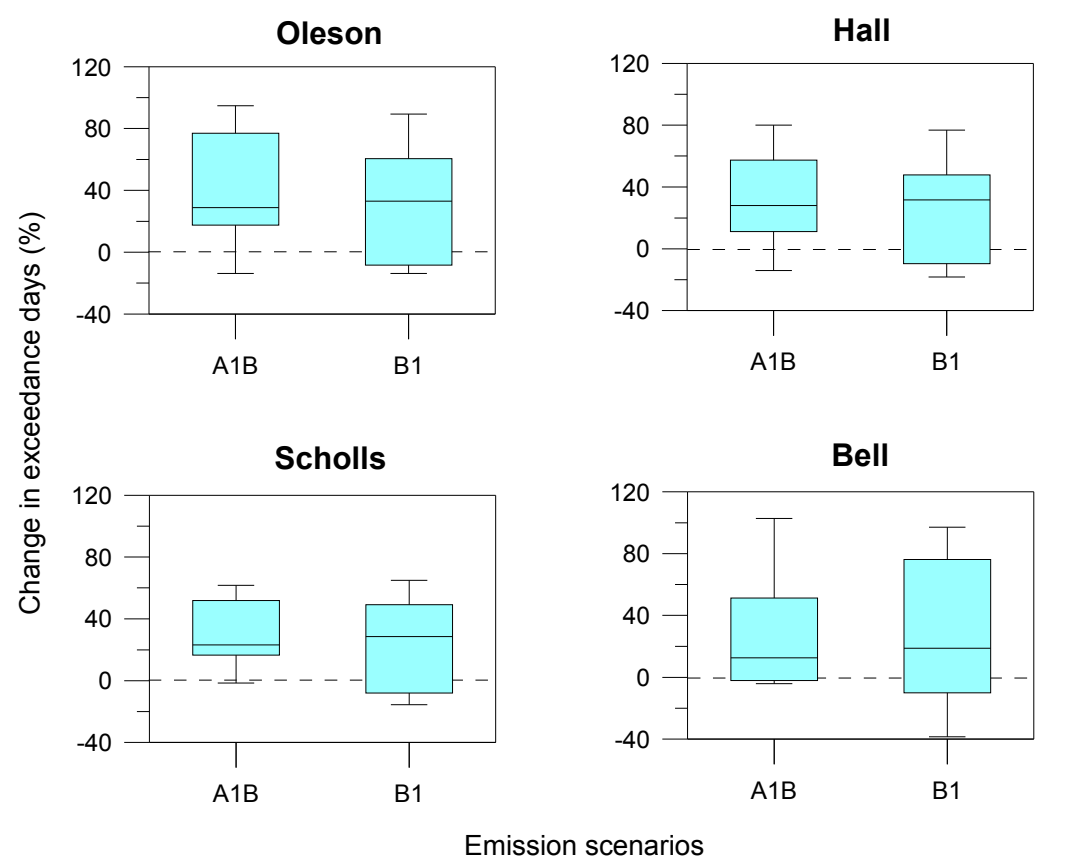

Figure 5. Changes in exceedance days with total days exceeding two-year recurrence flood interval for each subbasin

\subsection{Change in the probability of road flooding}

To evaluate future flooding impacts at actual road crossings identified by stakeholders, we conducted stream channel surveys at five different road crossings. We also conducted a hydraulic analysis with HEC-RAS, which has been used to find water-surface elevations for historical floods (Benito et al., 2003) and to model water flowing through bridges and culverts (Hotchkiss et al., 2008). With this approach, we determined the discharge value necessary to produce roadway flooding at each road crossing.

We surveyed and modeled road flooding at five different bridge sites. There are three sites on Fanno Creek: Oleson Road, upstream Hall Boulevard and the downstream Scholls Ferry Road crossing. The two sites on Johnson Creek were the Bell Avenue and Linwood Avenue crossings. Although the Fanno Creek watershed is highly urbanized, much of the creek flows through a wide, intact floodplain, consisting of restored areas, parks and greenways. All three sites in Fanno Creek have well-developed riparian areas and diverse channel form and substrate. In contrast, the two bridge sites surveyed on Johnson Creek are located in a portion of the creek that was channelized during the 1930s. At each location, the downstream Linwood Avenue (Linwood) and upstream Bell Avenue (Bell), the stream flows through a trapezoidal channel with brick-and-mortar walls and a relatively flat cobble and gravel bottom channel. Neither site has much riparian or in-channel vegetation.

Based on daily vehicle miles traveled, each road is classified as either an arterial or major arterial and, except for Oleson Road, also serves as a bus line. Four of the five locations have a history of flooding the road during large storms (Oregonian, 2007). The Scholls Ferry Road bridge is a relatively large span with no history of flooding; this site was selected as a probable example of a correctly sized structure with respect to climate-change induced flooding. All sites are located between USGS gauging stations. 
We collected the channel geometry data by following stream channel reference site protocol for wadeable streams (Harrelson et al., 1994). We surveyed four cross sections at each site, with two upstream and two downstream of the bridge, and captured the bridge geometry relative to the cross sections. At each cross section we noted the elevation at the top of the banks and the water-surface elevation; all cross sections and bridge information were tied to a common datum in order to model water flowing through the reach. Using a flow meter, we measured stream velocity at the furthest upstream cross section and, for the purpose of calibrating the models, estimated the roughness (Manning's $n$ ) at each cross section (Chow, 1959).

The stream channel data, both geometry and flow data, were analyzed in HEC-RAS (version 4.0) to determine water-surface elevations for a given discharge. HEC-RAS is a onedimensional steady flow model that calculates water-surface height as a function of discharge, channel geometry, and energy losses due to friction (Manning's equation) and the expansion/contraction of flow through between cross sections. We conducted a combined steady flow analysis using the bridge routine. This routine allows us to enter the bridge geometry and the location of any pillars as a barrier to flow, and also to define areas of ineffective flow. We established values for Manning's $n$ based on field observation for both in channel on over-bank flow. For the model, we set a Manning's number for resistance to instream and overbank flow based a comparison between descriptions in Table 3 of the HEC-RAS Hydraulic Reference Manual (USACE 2010) and field observations of bed forms and floodplain vegetation, respectively.

The HEC-RAS model output shows that all cross sections, with the exception of Scholls Ferry Road, are inundated during the current 25-year flood event (Figure 6). However, the crossings diverge somewhat for smaller events. The Oleson Road crossing floods much more frequently; this crossing area has an active floodplain upstream of the bridge, but is controlled downstream by a wooden wall and riprap. This crossing is well known as a problem flood area, and our modeling simply reinforces the frequency with which this bridge can become impassable due to flooding. The Hall Boulevard crossing is flooded during less than a 25 -year magnitude event; this crossing has a much more extensive floodplain than the Oleson Road crossing and the channel is not constricted other than when passing through the bridge. Yet, the bridge opening itself is not large; hence, this road is subject to fairly frequent flooding. This bridge is crowned, as is Scholls Ferry Road, and the stream does not cover the bridge during any flood; however, water does flow across the road in the floodplain during high water, which leads to closure of this crossing. With a large floodplain and a large bridge opening, the Scholls Ferry Road crossing does not flood at any discharge; however, the bike path adjacent to the stream that goes under the bridge is often inundated. 

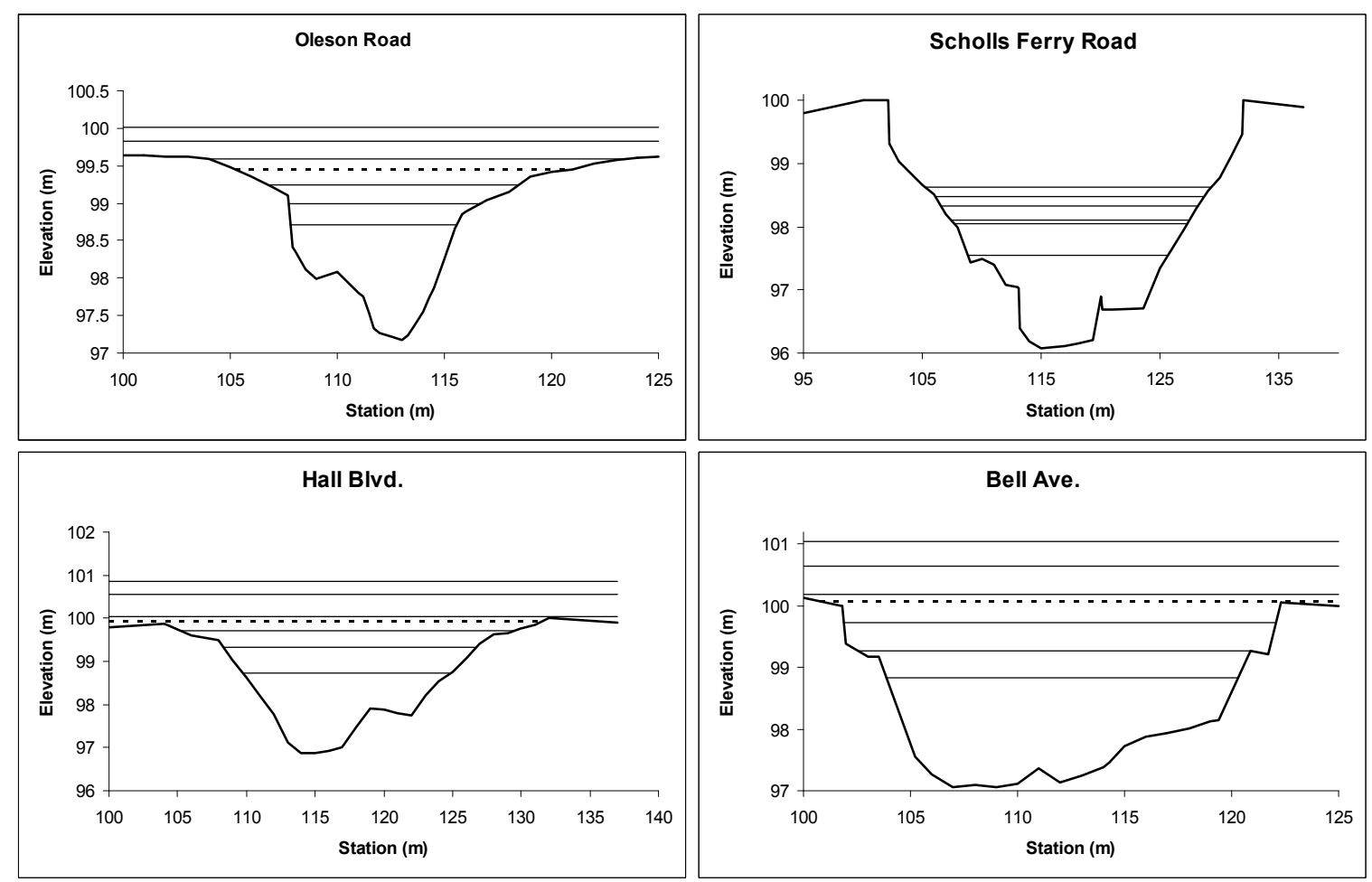

Figure 6. Stream channel cross sections with solid horizontal lines indicating the water-surface elevations for, from bottom to top, the two-year, five-year, 10-year, 25-year, 50-year and 100-year events. The dashed line indicates the water-surface elevation when water first begins flooding the road; this never occurs at Scholls Ferry Road. Linwood Avenue is nearly identical to Bell Avenue, so the stream channel cross section is not reported here.

The bridge openings in Johnson Creek are much larger than most bridge openings in Fanno Creek, a legacy of channelization in Johnson Creek. Yet, each crossing site floods just prior to a 25-year event. Like the Hall Boulevard site, these roadways begin flooding before water overtops the bridge itself. In the case of the Bell Avenue crossing, water will actually flow north of the stream channel, through a parking lot, and across the road approximately three meters north of the bridge itself. Hence, this road is closed more frequently than would be expected by our models.

A larger problem for the Johnson Creek crossings is that the rock walls that act as the banks for these reaches will not allow for these channels to widen as annual discharges increase with climate change. Thus, the only erosion that will be taking place at these locations is incision into the streambed, which may compromise the bridge structures over time. Both of these locations, as well as each location in Fanno Creek, have large boulders in place at the downstream edge of the bridge opening to prevent a nickpoint from migrating through the bridge. Hence, the Johnson Creek crossings will require vigilant maintenance of these "toedowns" in order to prevent incision. Unfortunately, this will also lead to more frequent flooding as there is no opportunity for stream channel adjustment. In Fanno Creek, these crossings do have some room to expand their banks. The concern at these sites will likely be the timing of geomorphic adjustment relative to the timing of increased discharge. For instance, if the stream channel adjustment lags behind the pace of discharge increase and the increases are small, these sites will experience more frequent small events. Unfortunately, these small events, which do 
flood the roadways, do little to expand the size of the channel and will only exacerbate roadway flooding.

The classic model of stream channel evolution states that channels in dynamic equilibrium are sized to accommodate the discharge associated with approximately the one and a half-year to two-year flow return discharge (Leopold et al., 1964). At higher discharges streams would then flood into their floodplains. This "bankfull" discharge, often referred to as effective discharge, would actually be lower than the top of the banks if a stream had incised into its channel because of change in flow regime. Urbanized watersheds, with relatively high amounts of impervious surface, have been shown to both incise and widen in response to urbanization (Hammer, 1977). As such, the two-year flow return interval is likely to be lower than the current bankfull elevation if stream enlargement has taken place.

Our results show that while floods depend on precipitation intensity, volume and timing, they also rely on drainage basin and local geomorphic characteristics. However, given the predicted increases in flood return exceedance for smaller floods (Figure 6), nuisance flooding is likely to become more common at these cross sections. As illustrated in this study, restoration of floodplains will serve as proactive adaptation strategies in reducing flood damage under a changing climate. In addition, future flooding potential could be further reduced as best management practices such as porous pavement or detention ponds are implemented. In particular, older neighborhoods (e.g., lower Johnson Creek) would be good candidate areas for implementing these practices. 


\section{5 - Impacts on transportation cost}

\subsection{Cost classification}

Flooding costs are highly dependent on the magnitude and duration of each event. This research classifies flooding costs into five categories based on who bears the cost, whether the cost is a direct result of the damaging power of high water flows and strong currents, and whether the costs are the result of higher flooding risks.

\subsubsection{Direct costs to public infrastructure and public agencies}

These are the direct costs associated with flooding and borne by public agencies and utilities (i.e., damages and costs that are incurred during the flood itself, such as the operation of an emergency management system or any construction costs needed to restore roads and facilities to pre-flood conditions). A detailed list includes:

- Emergency Response Costs: This includes all costs related to staffing and managing emergency management centers (EMC), flaggers, and traffic control supervisors. It also includes costs associated with equipment and installation of temporary gates, amber flashers, temporary barricades, sediment fences, portable variable message signs (VMS), temporary drainage facilities, vehicle towing, and responses from ambulances, police, and fire brigades.

- Repair Costs: This includes bridge, culvert, and drainage repairs, pavement resurfacing or replacement, signs, guardrails, striping, landscaping, as well as repairs to public utility infrastructure such as electrical, phone, water, sewer, cable and gas systems.

\subsubsection{Direct costs to the population and private property}

These are the direct costs associated with flooding and borne by individuals. Examples include health costs (including injury treatment, rehabilitation and fatality costs) as well as private property damage (vehicles, equipment, buildings, etc.).

\subsubsection{Indirect costs due to delays or reduced accessibility}

These are the indirect costs caused by a loss of accessibility due to road closures or reduced transportation capacity. Examples include congestion costs incurred by private vehicles, transit operators and passengers, and freight vehicles, as well as business costs including loss of sales, missed shipments and production costs.

\subsubsection{Tangible costs due to higher risk}

These incremental costs are associated with preventive measures to avoid the negative consequences of future floods by building new or upgraded infrastructure and facilities. These costs are computed as the difference between total post-flooding construction costs and reconstruction costs to restore infrastructure and facilities to pre-flooding conditions (computed in point (a)). For example, the construction of new flooding walls or the incremental costs associated with reinforcing or raising a bridge above pre-flooding levels.

\subsubsection{Intangible costs due to higher risk}

These costs are intangible because they are a consequence of changes in perceived risk. These types of costs are associated with the consequences of higher flood risks and land use 
changes, such as increases in flood insurance premiums as well as loss of property and business value.

Given that the magnitude and frequency of weather events are stochastic variables, a probability risk assessment (PRA) methodology is appropriate to quantify flooding costs. However, the quantifying and analysis of climate change costs on local transportation infrastructure is greatly obscured by: (i) the uncertainty related to the estimation of the incremental impacts of climate changes on flood event magnitude, frequency and duration, and (ii) the lack of systematic and consistent cost data records for events of different levels of magnitude and duration.

\subsection{Cost estimation and sensitivity analysis for flooding}

The participation of affected local agencies was central in determining transportation costs associated with flooding. Stakeholders in this research include Clackamas and Washington counties, Tualatin Valley Fire and Rescue and Metro, an elected regional government serving three counties and 25 cities in the Portland region. Reconstruction cost data were provided by the Clackamas County Department of Transportation and Development and the Washington County Department of Land Use and Transportation. Metro provided traffic and land use data and projections.

Due to the lack of data regarding the incremental impacts of climate change due to higher risk, this section focuses on the quantification of direct and indirect costs (i.e., costs (a), (b), and (c) in the previous section). A sensitivity analysis is also performed to analyze the effect of highimpact but highly uncertain costs such as fatalities. In addition, the focus is on typical flooding since there are no consistent or reliable data for events of higher magnitude. Typical flooding is defined as an event where the water level impedes safe utilization of the roadway. For the analyzed crossings, a typical flooding event takes place between 10-year and 20-year recurrent flood flows (Suarez et al., 2005). The following subsections provide some reference values. Under a severe climate change scenario, the frequency of typical flooding is likely to double.

\subsubsection{Direct costs to public infrastructure and public agencies}

Direct costs to public infrastructure and public agencies greatly vary depending on the magnitude and duration of each event. A site visit was performed for both study areas to conduct an inventory of signage, and to estimate the length of guardrails, striping and landscaping. These estimates were verified with ArcGIS measurements. Finally, the measures were used in calculating the costs for each item. A list of these typical expenses is shown in Table 2. These costs are based on prices used by the Oregon Department of Transportation (ODOT, 2009). Each item applicable to the study area was estimated. Staff and reconstruction costs for a typical annual event are approximately $\$ 143,552$. The full and detailed estimation is found in Table 4 .

Table4. Estimated direct costs of a typical flooding event

\begin{tabular}{|c|c|c|}
\hline Item & Unit & Average Price \\
\hline \multicolumn{3}{|l|}{ Short Term } \\
\hline Amber Flashers & Each & $\$ 85.00$ \\
\hline Temporary Barricades & Each & $\$ 51.90$ \\
\hline
\end{tabular}




\begin{tabular}{|l|l|r|}
\hline Portable VMS & Each & $\$ 7,526.28$ \\
\hline Temporary Gates & Each & $\$ 1,000.00$ \\
\hline Sediment Fence & Lineal Feet & $\$ 3.53$ \\
\hline Temporary Drainage Facilities & Lump Sum & $\$ 24,022.00$ \\
\hline Staff and Equipment & $\$ 34.49$ \\
\hline Flaggers & Hour & $\$ 307.80$ \\
\hline Traffic Control Supervisor & Day & $\$ 45.19$ \\
\hline Vehicle to Move Equipment & Hour & $\$ 15.86$ \\
\hline Long Term & \multicolumn{2}{|l|}{} \\
\hline Signs & Square Feet & $\$ 0.14$ \\
\hline Striping & Lineal Feet & $\$ 20.00$ \\
\hline Guardrail & Lineal Feet & $\$ 86.40$ \\
\hline Landscaping Replacements & Each &
\end{tabular}

\subsubsection{Direct costs to the population and private property}

One fatality occurred in the past 10 years as a result of a vehicle being swept away during a flood. The cost of a fatality is by far the largest cost potentially associated with flooding in our research. This research uses a value of \$2.6 million per fatality, as adopted by the Federal Highway Administration. This value includes the effects of a person's entire life, such as lost earnings, lost household production, medical expenses, funeral expenses, emergency services, administrative costs and legal costs (FHA, 2009). There are no records of significant private property losses in the last 10 years. It is important to highlight that other government agencies, such as the U.S. Environmental Protection Agency, may have higher cost estimates.

\subsubsection{Indirect costs due to delays or reduced accessibility}

The traffic impact analysis began with the identification of transportation network links (i.e., bridges, road segments or streets that are expected to flood based on the findings from the climate and hydrological analysis). A list of transportation links that are prone to flooding are included in Table 5.

Metro's regional travel model was utilized to measure the potential disruption and costs of flooding to the transportation system. For travel forecasting purposes, land use assumptions are divided into geographical areas called transportation analysis zones (TAZs). The TAZ is the "unit geography" for travel within the demand model. Households and employment estimates are assigned to each TAZ. Metroscope, a simulation model developed by Metro to evaluate urban land use planning policies, was used to generate and assign future household and employment projections. Metroscope utilizes extensive data sets, including land and real estate values, vacant and buildable land supply, redevelopment and infill land, environmental conditions, transportation network attributes, development trends, and population and growth projections, to determine the relative attractiveness of areas within Portland's urban areas. Expected growth in employment and households are then assigned to TAZs. Local agencies review and refine the assignments within a regional control area. All the trips generated by the land use elements are aggregated and analyzed at the TAZ level. Initial one-hour mid-day and two-hour evening peak traffic assignments were run using software to establish baseline traffic volumes and link volumes and capacities for 2005 and 2035. Traffic assignments were then rerun with the flooded 
network links removed for both the Fanno Creek and Johnson Creek study areas. Using this output, a flood area of influence, comprised of TAZ clusters, was identified for each study area.

Transportation evaluation measures were produced for each flood area of influence that included vehicle miles traveled, vehicle hours traveled and vehicle hours of delay (VHD) for the one-hour mid-day and two-hour evening peak travel periods in the two study sites. Network flows were obtained from solving a Deterministic User Equilibrium (DUE) problem (Bell and Lida, 1998) using transportation planning software EMME2.

The Fanno Creek and Johnson Creek flood area of influence generate an estimated 973,000 and 541,000 vehicle miles traveled (VMT), respectively, in the two-hour p.m. peak travel period. Together, these areas account for 24 percent of the total VMT generated in the 4-6 p.m. travel period. Both study areas are located in suburban locations where the arterial street network is fairly complete, but the local street network is often discontinuous. Table 5 lists the street links prone to flooding and the average traffic volume they carry in the two-hour p.m. peak travel period for the base year 2005 and future year 2035.

Table 5. Changes in average traffic volume as a result of road closures for 2005 and 2035.

NB - northbound travel $\quad \mathrm{SB}$ - southbound travel $\quad$ EB - eastbound travel $\quad \mathrm{WB}$ - westbound travel

\begin{tabular}{|l|c|c|c|c|}
\hline \multicolumn{1}{|c|}{ Facility } & \multicolumn{3}{c|}{ Two-hour p.m. peak } \\
\hline SW Oleson Rd & \multicolumn{2}{|c|}{2005} & \multicolumn{2}{c|}{$\mathbf{2 0 3 5}$} \\
\hline SW Hall Blvd & $900 \mathrm{NB}$ & $1200 \mathrm{SB}$ & $1000 \mathrm{NB}$ & $1400 \mathrm{SB}$ \\
\hline SE Johnson Creek Blvd & $3800 \mathrm{NB}$ & $2800 \mathrm{SB}$ & $4400 \mathrm{NB}$ & $3300 \mathrm{SB}$ \\
\hline SE Bell St & $1800 \mathrm{~EB}$ & $1600 \mathrm{WB}$ & $2800 \mathrm{~EB}$ & $2300 \mathrm{WB}$ \\
\hline SE Linwood St & $400 \mathrm{NB}$ & $600 \mathrm{SB}$ & $500 \mathrm{NB}$ & $800 \mathrm{SB}$ \\
\hline
\end{tabular}

NB - northbound travel $\quad \mathrm{SB}-$ southbound travel $\quad \mathrm{EB}-$ eastbound travel $\quad \mathrm{WB}-$ westbound travel

An evaluation of the travel model output for the Fanno Creek and Johnson Creek flooding areas of influence forecasted negligible increases (less than 1 percent) in vehicle miles traveled in both travel periods for 2005 and 2035 when flooded links were removed from the street network. An assessment of VHD demonstrated a greater impact from flooding. Closing facilities in the Fanno Creek shed caused over 200 additional hours of delay in the p.m. peak period. The base and future years showed similar increases in hours, but the percent increase is much higher for 2005. The Johnson Creek shed's increase ranged from 4 percent in the base year to 3.4 percent in the future. The impacts of closing these facilities due to flooding are minimal on overall miles traveled, but they do reveal that other roadways will be more congested, resulting in greater delay because the diverting vehicles and existing vehicles are all affected. 


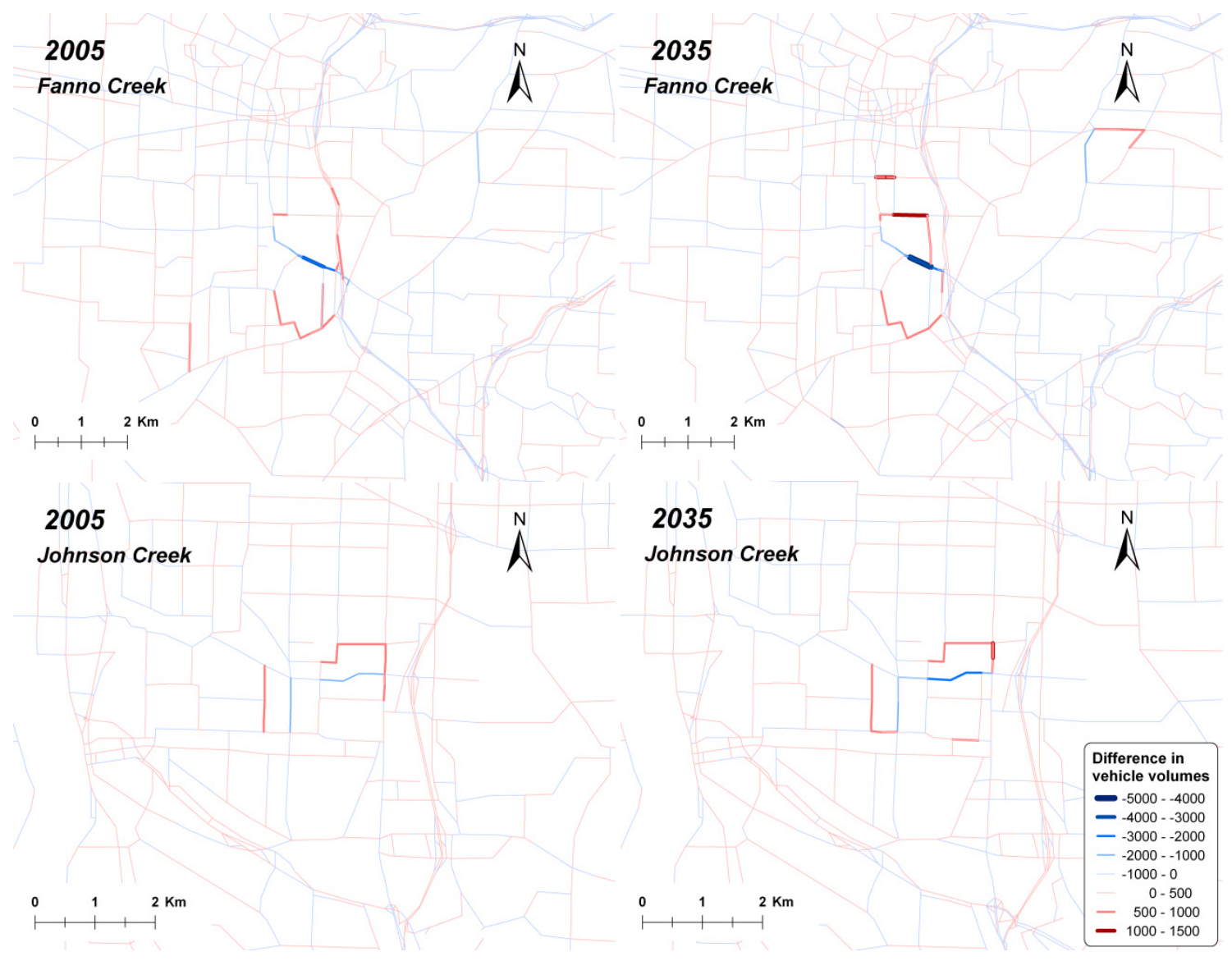

Figure 7. Changes in travel disruption as a result of road closure, 2005 and 2035 for Fanno Creek and Johnson Creek

The region-wide modeled transportation network provides several alternative arterial routes to the flooded links. The macro-level equilibrium traffic assignment assumes that travelers have perfect knowledge of the road conditions (without any incidents), and which additional routes are available in time to make an informed decision about the path they will take. Therefore, the resulting statistics may underestimate the level of out-of-direction travel that would contribute to an increase in vehicle miles traveled during short-term flooding.

The following is a list of assumptions made to analyze the transit passengers' and private vehicle drivers' value of time. The bus capacity was estimated by visual observations made during peak and non-peak times on local buses.

- Average bus speed is $25 \mathrm{mph}$

- Bus is at 15 percent capacity during off-peak times

- Bus is at 40 percent capacity during peak times

- Bus holds 72 passengers

- 23.5 percent of bus service is during a peak hour

- 76.5 percent of bus service is during an off-peak hour

- Peak hours are 7-9 a.m. and 4-6 p.m.

- Peak hours are considered congested in this analysis

- Non-peak hours are considered uncongested 
Passenger time was estimated at 60 percent of wage rates for motorists, while a value of 40 percent of wage rates was used for passengers in uncongested conditions. The values were increased to 90 percent and 60 percent, respectively, when experiencing congestion assumed at peak travel hours. The two counties in the study areas have approximately the same average household income of $\$ 52,100$, with a wage rate of $\$ 29$ per hour (Washington County, 2009). The values of time used are as follows:

- Transit passenger: $\$ 11.60$ (non-peak travel), $\$ 17.40$ (peak travel)

- Private Vehicle Driver: $\$ 17.40$ (non-peak travel), $\$ 26.10$ (peak travel)

The Tri-County Metropolitan Transportation District of Oregon, known as TriMet, is the public agency that operates the mass transit system in the metropolitan area. Within the Johnson Creek study area, TriMet operates one bus line that would be affected by flooding; the Fanno Creek area has three bus lines that would be affected. Each affected bus line was rerouted to avoid flooded roadways and keep buses off of neighborhood streets. The Fanno Creek alternate route utilizes Southwest Hart Road, Southwest Murray Boulevard and Southwest Scholls Ferry Road to keep traffic off of Hall Boulevard. The Johnson Creek alternate route uses Southeast $82^{\text {nd }}$ Avenue and Southeast Flavel Street to divert traffic from Johnson Creek Boulevard. Additionally, the routes were selected to keep transit customers within one-quarter or a half mile of the nearest bus stop. One-quarter to one-half mile are suggested by studies as the distance that people are willing to walk to a bus stop (Dittmar and Ohland, 2003). Most American cities in 2005 used an operating and maintenance cost in the range of $\$ 80$ to $\$ 120$ per hour per bus. TriMet uses a value of $\$ 98.73$ per hour per bus. The buses used by TriMet have capacity for 55 sitting passengers and 17 standing passengers. Public transportation delay costs were estimated assuming an average bus speed of 25 miles per hour and 15 and 40 percent capacity utilization during non-peak times and peak time times, respectively. These values for the bus service speed and utilization were validated by TriMet. The values reflect additional miles in an alternate route when compared to the regular route. Johnson Creek had a total transit delay cost of $\$ 8,788$, while Fanno Creek had a slightly higher total transit delay cost of $\$ 9,074$ because more bus lines would be affected by flooding.

The cost of freight was based on recommendations from the National Cooperative Highway Research Program (NCHRP) report (TRB, 2001). The report suggests that carriers' value of freight transit time can be estimated in the range $\$ 144.22$ to $\$ 192.83$ per hour; carriers' value of freight transit time escalates during a delay to $\$ 371.33$ per hour. The delay cost was multiplied by the number of VHD as determined by the Metro regional model. This research adopts the higher end value, $\$ 371.33$ per hour of delay. Commercial vehicle hours of delay amount to seven hours in Fanno Creek and one hour in Johnson Creek. Total freight delay costs amount to $\$ 2,971$.

\subsubsection{Cost and sensitivity analysis}

Due to the high dollar amount associated with a fatality, Table 6 is divided into two sections: without a fatality (top section) and with a fatality (bottom section). As shown in Table 6, repair and cleaning costs are considerably higher than accessibility costs due to delays. Transit costs are significantly higher than private vehicle costs. 
Table 6. Estimated typical flooding costs with and without fatalities

\begin{tabular}{|l|r|r|}
\hline \multicolumn{2}{|l|}{ Total costs without fatalities } & \multicolumn{2}{|l|}{ Costs } & Percent of Total \\
\hline Repair and Cleaning Costs & $\$ 143,551$ & $84.4 \%$ \\
\hline Transit Delay Costs & $\$ 17,861$ & $10.5 \%$ \\
\hline Private Vehicle Driver Delay Costs & $\$ 5,715$ & $3.4 \%$ \\
\hline Freight Delay Costs & $\$ 2,971$ & $1.7 \%$ \\
\hline Total & $\mathbf{\$ 1 7 0 , 0 9 8}$ & $\mathbf{1 0 0 . 0 \%}$ \\
\hline Total costs with a fatality & & Percent of Total \\
\hline Immediate, Staff, Reconstruction Costs & $\$ 143,551$ & $5.2 \%$ \\
\hline Transit Delay Costs & $\$ 17,861$ & $0.6 \%$ \\
\hline Private Vehicle Driver Delay Costs & $\$ 5,715$ & $0.2 \%$ \\
\hline Freight Delay Costs & $\$ 2,971$ & $0.1 \%$ \\
\hline Fatality Costs & $\$ 2,600,000$ & $93.9 \%$ \\
\hline Total & $\mathbf{\$ 2 , 7 7 0 , 0 9 8}$ & $\mathbf{1 0 0 . 0 \%}$ \\
\hline
\end{tabular}

The study areas have had only one fatality in the last five years, when a driver in the Johnson Creek watershed was washed away inside a vehicle. Fatalities are undoubtedly the most expensive cost element. However, the estimation of climate change impacts on the probability of having a fatality was beyond the scope of this study. It is now evident that the estimation of probabilities associated with fatalities during flooding requires further research and analysis. In addition, due to lack of data this research has not included costs associated with the increased risk of flooding due to climate change or rescue costs.

\subsubsection{The impact of climate change}

In the study area for most crossings the area of the sub-basins are less than 12 square miles, the road density is approximately 18,000 miles per square mile, and the land use is predominantly urban (around 80 percent). Under a severe climate change scenario, the frequency of typical flooding may double. It is then expected that the direct costs associated with these events would at least double. Assuming that typical flooding has a 10 -year recurrence, a preliminary estimation of the additional costs of climate change indicates that the annual costs associated with climate change in urban creeks is approximately $\$ 20,000$ and $\$ 280,000$ dollars per year without and with a fatality, respectively.

It must be emphasized that these estimations do not take into account tangible and intangible costs due to higher risk. In addition, the impacts of heavier rain on urban flooding are non-linear and subject to local hydroclimate and geomorphic conditions as well as road/bridge designs. Furthermore, the likelihood of fatalities and the damage rate may also increase at a non-linear rate. Unfortunately, there is no data available to test this hypothesis (see Section 6). Rescue costs (i.e., successful rescues without fatalities) and their frequency are also difficult to estimate, and they are not included in the estimates provided in this section. Nonetheless, these simplifying assumptions and preliminary estimates are helpful to provide a cost range for public agencies and decision makers. To the authors' knowledge, before this study was conducted there were no estimates regarding the cost of climate change or even the cost of flooding in the Portland region. There is a clear need for additional research efforts and cost-effectiveness analysis. 


\section{6 - Recommendations}

Local agencies need to address maintenance of data archives for flooding events. Existing data is incomplete and difficult to compile and analyze. The lack of data and the unavailability of necessary information to incorporate climate change into transportation decisions make it difficult for transportation agencies to plan for such phenomena. A repository of data pertaining to flooding in the Portland region will undoubtedly be useful for planning and evaluation purposes. Ideally, this archive will include data and trends regarding the five types of costs identified in cost classification. The optimal design and management of a "transportation climate change data archive" is a non-trivial task that requires further study and consideration. Table 6 includes a list of data items that may be required for a comprehensive evaluation of the monetary impacts of flooding costs, infrastructure upgrades and changes in risk perceptions. The relative weight and importance of the different items will be location-specific. This list is meant to illustrate the vast data requirements, and it should be noted that necessary climate and hydrological data needs are not included here.

Assessing risk and vulnerability of the transportation network may require new approaches to the design and planning of investments in transportation infrastructure that use probabilistic, rather than deterministic, analysis. These study areas have had only one fatality in the last five years. Future studies should specifically study fatality probabilities based on varying magnitudes of rain events. This will allow for a more precise comparison of costs and the evaluation of cost-benefit analysis for infrastructure improvements. Similarly, future studies should address tangible and intangible climate change costs associated with the increased risk of flooding.

Public awareness regarding flood risks and liabilities should also increase. Oregon law gives search and rescue agencies the authority to charge subjects of searches and rescues up to \$500 apiece when "reasonable care" was not used and when "applicable laws were violated" (Smith, 2009). Other states, such as Arizona, have adopted harsher laws. In 1996, Arizona adopted a statute stating "liability for emergency responses in flood areas can be charged to the driver" (Arizona Revised Statutes, 2009); this statute is popularly known in the media and public as the "stupid motorist law." Public awareness of these laws can serve as a tool to discourage motorists from entering flooded roadways and reduce potential fatalities. Agencies must take a coordinated approach to let the public know that they can be held responsible for costs associated with their rescue. Figure 8 illustrates a case where drivers are crossing a flooded roadway and, despite the lack of flood signage, the motorist can be held responsible for rescue costs. 


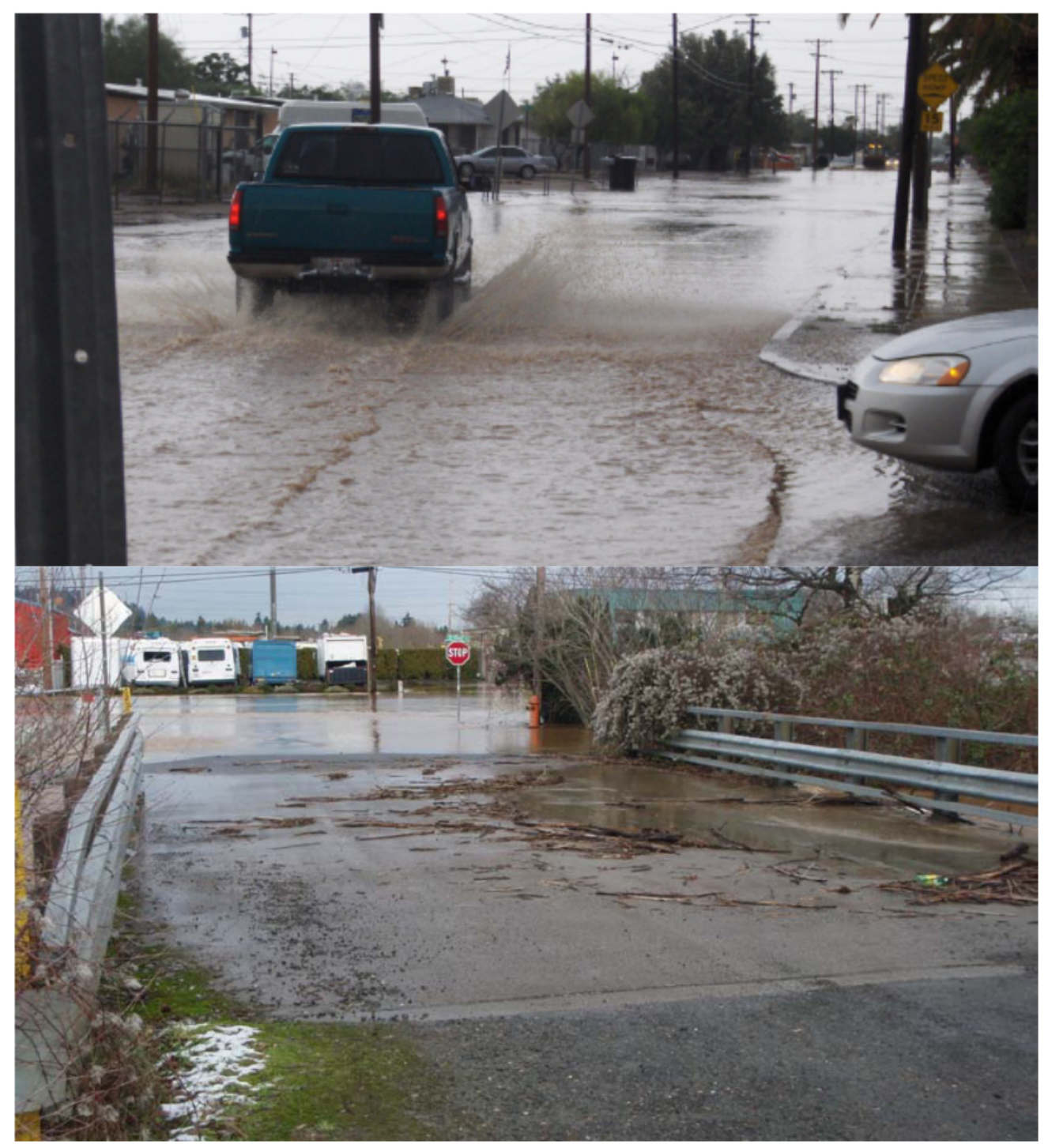

Figure 8 - Motorists crossing a flooded roadway (top), Johnson Creek crossing after Jan. 2, 2009 rain (bottom)

The implications of climate change for transportation and land management in the area under study are multiple. This preliminary analysis breaks them down into (a) short-term and (b) long-term implications and recommendations. Table 4 summarizes recommendations broken down further by cost level and time.

Short-term recommendations include the increasing need to effectively coordinate and respond to more frequent weather events by the affected agencies. Additional emergency traffic control and personnel may be required. It is also expected that a greater utilization of sensors and smart technologies will be needed to monitor and communicate changing water levels to emergency centers and Intelligent Transportation Systems (ITS). Inventory of culverts in the area, as well as inventory of those areas with problematic drainage systems, should be incorporated using Geographic Information Systems (GIS). Effective communication and response mechanisms can greatly reduce the loss of human life (e.g., timely evacuation and closures), the largest expense related to flooding, and reduce congestion costs (e.g., giving 
advance warning to drivers and suggesting alternate routes). Future research should include the cost effectiveness of these measures.

Long-term implications will most likely be seen in infrastructure maintenance, design and management, as well as land use planning. Alternative routes to problematic areas will need to be determined. Maintenance costs will escalate as more erosion problems occur in flood-prone areas. Infrastructure design is likely to become more costly as the greater uncertainty associated with climate change will require more expensive designs. Infrastructure inventory and management systems are likely to incorporate scenario analysis to identify transportation system resiliency and vulnerability to climate change. Further, budget prioritization of infrastructure upgrades and retrofitting will be necessary to minimize the loss of critical transportation links over the long-term planning period. Land use planning is likely to focus on prevention and risk reduction, discouraging development in areas prone to flooding and encouraging land management and building practices that reduce or delay rainfall peak flows. Affected jurisdictions may need to consider long-term acquisition and protection of open space in related floodplains, and raising elevation requirements for any new development that does occur in the identified areas.

Table 7. Recommendations for short- and long-term response measures

\begin{tabular}{|c|c|c|}
\hline & Low Cost & ligh Cost \\
\hline $\begin{array}{l}\text { Short } \\
\text { Term }\end{array}$ & $\begin{array}{l}\text { Public education and outreach programs } \\
\text { regarding flooding and safety. } \\
\text { Public awareness regarding "stupid } \\
\text { motorist laws." } \\
\text { Conduct inventory of watershed } \\
\text { topography, ecological survey, } \\
\text { hydrology/hydraulic modeling. }\end{array}$ & $\begin{array}{l}\text { Installing ITS measures such as flood sensors } \\
\text { and warning system on affected roadways } \\
\text { and bridges. } \\
\text { Upgrading emergency management centers. } \\
\text { Installation of temporary flood control } \\
\text { structures. }\end{array}$ \\
\hline $\begin{array}{l}\text { Long } \\
\text { Term }\end{array}$ & $\begin{array}{l}\text { Coordinated multi-agency flood costs } \\
\text { data collection and record keeping. } \\
\text { Monitoring the impacts of climate } \\
\text { change and studying flood prevention } \\
\text { measures cost effectiveness. } \\
\text { Land use restrictions, mandatory } \\
\text { detention ponds, and porous pavements. }\end{array}$ & $\begin{array}{l}\text { Land use changes; business and residential } \\
\text { relocations. } \\
\text { Raising elevation requirements and } \\
\text { infrastructure. } \\
\text { Acquisition and protection of open space in } \\
\text { floodplains to prevent future development, } \\
\text { floodplain restoration. }\end{array}$ \\
\hline
\end{tabular}

These recommendations reflect the alternatives available in the study areas and are not meant to be a comprehensive list of recommendations for all possible areas of study. The interested reader is referred to these [24][25] studies for a more comprehensive list of mitigation and adaptation measures. 


\section{7 - Conclusions}

Global climate change will have significant impacts, particularly in urban areas where many socioeconomic activities are concentrated (Chang and Franczyk, 2008). Many growing urban areas such as the Pacific Northwest will experience higher amounts and intensity of winter precipitation. In projecting future flood frequency, there are high uncertainties associated with global climate model structure and emission scenarios. Despite this uncertainty, the 5-year, 10year and other relatively small events are likely to increase in all study sites that have a history of chronic flooding. Stream channels will likely lag in adjusting to the new, slowly increasing discharge regimes and may not be able to adjust at bridge locations, which is likely to further exacerbate roadway flooding. While vehicle miles traveled in both periods show negligible increases, vehicle hours of delay demonstrated a greater impact from flooding. The estimates are, however, conservative as the current approach assumes the traveler's perfect knowledge regarding the closure of road crossings.

Our results show that there is a nonlinear relation between precipitation change and urban flooding, and that impacts on travel disruption are subject to local hydroclimate and geomorphic conditions. Although it is a specific case study, the integrated methodology used in this study can be applied to other urban areas facing similar transportation impacts in a changing climate. If climate change, watershed hydrology, channel morphology and transportation networks are readily available in a spatial database, it could even be possible to upscale a similar model to regional or national levels. However, the complex interactions of a changing precipitation regime, adjustments in channel morphology, and human response and adaptation to flooding still need to be further investigated. Additionally, estimating the costs associated with flooding events was difficult due to the lack of complete and systematic records. In addition, properly quantifying and analyzing climate change costs on local transportation infrastructure is greatly obscured by the uncertainty related to the estimation of the incremental impacts of climate change on flood event magnitudes, frequencies and durations. Flood-related costs are extremely sensitive to the occurrence of fatalities or personal injuries. Therefore, the likelihood of fatalities and personal injuries should be included in future research efforts and cost-effectiveness analysis.

Despite some of these limitations, this study is one of the few interdisciplinary attempts to assess potential impacts of climate change on the transportation sector. The integration of the top-down and the bottom-up approaches involving local stakeholders at the beginning of the project demonstrates a useful tool to assess climate change impacts at a local scale. A participatory regional integrated assessment tool found in other sectors such as water resources and agriculture (e.g., Holman et al., 2008) could be adapted for the transportation sector. Such integrated knowledge and spatially explicit modeling is essential for establishing proactive flood and transportation management planning and policies under increasing climate uncertainty. 


\section{References}

Arizona Revised Statutes. 2009. Title 28 Enacted 1996.

http://www.azleg.state.az.us/FormatDocument.asp?inDoc=/ars/28/00910.htm\&Title=28\&DocType =ARS. Accessed Jul. 24, 2009.

Bae, D. H., I. W. Jung, and H. Chang. 2008. Potential changes in Korean water resources estimated by high-resolution climate simulation. Climate Research 35: 213-226.

Bell, M.G. and Y. Iida, 1997. Transportation network analysis, Wiley.

Benito, G., A. Diez-Herrero, and M. F. de Villalta, 2003. Magnitude and frequency of flooding in the Tagus basin (Central Spain) over the last millennium. Climatic Change 58: 171-192.

Black, W. R., and N. Sato. 2007. From global warming to sustainable transport 1989-2006. International Journal of Sustainable Transportation 1: 73-89.

Burlando, P., and R. Rosso. 2002. Effects of transient climate change on basin hydrology. 1. Precipitation scenarios for the Arno River, central Italy. Hydrological Processes 16:11511175.

Cameron, D. 2006. An application of the UKCIP02 climate change scenarios to flood estimation by continuous simulation for a gauged catchment in the northeast of Scotland, UK (with uncertainty). Journal of Hydrology 328: 212-226.

Carter, T. R., R. N., Jones, X. Lu, S. Bhadwal, C. Conde, L. O. Mearns, B. C. O’Neill, M. D. A. Rounsevell, and M. B. Zurek. 2007. In Climate Change 2007: Impacts, Adaptation and Vulnerability. Contribution of Working Group II to the Fourth Assessment Report of the Intergovernmental Panel on Climate Change, eds. M.L. Parry, O.F. Canziani, J.P. Palutikof, P.J. van der Linden, and C.E. Hanson. Cambridge: Cambridge University Press.

Chang, H., and J. Franczyk, 2008. Climate change, land cover change, and floods: toward integrated assessments. Geography Compass 2 (5): 1549-1579.

Chang, H. 2007. Streamflow characteristics in urbanizing basins in the Portland Metropolitan Area, Oregon, USA, Hydrological Processes 21(2): 211-222.

Changnon, S. D. 2003. Measures of economic impacts of weather extremes. Bulletin of the American Meteorological Society 54:1231-1235.

Chapman, L. 2007. Transport and climate change: a review. Journal of Transport Geography 15: 354-367.

Chow, V. T. 1959. Open-Channel Hydraulics. New York: McGraw-Hill, Inc.

Cooper, R. M., 2005. Estimation of peak discharges for rural, unregulated streams in Western

Oregon. U.S. Geological Survey Scientific Investigations Report 2005-5116, 134 p.

Compton, K., T. Ermolieva, and J. C. Linnerooth-Bayer, 2002. Integrated flood risk management for urban infrastructure: managing the flood risk to Vienna's heavy rail mass rapid transit system. Proceedings of the Second Annual International IASA-DPRI Meeting: Integrated disaster risk management: megacity vulnerability and resilience, Laxenburg, Austria, International Institute for Applied Systems Analysis, 20 pp.

Dagnachew, L, V. C. Christine, and G. Francoise, 2003. Hydrological response of a catchment to climate and land use changes in tropical Africa: case study south central Ethiopia. Journal of Hydrology 275:67-85.

Dobney, K., C.J., Baker, A.D. Quinn, and L. Chapman. 2009. Quantifying the effects of high summer temperatures due to climate change on buckling and rail related delays in South-east United Kingdom. Meteorological Applications 16: 254-261 
Federal Highway Administration (FHA). 2009. Motor Vehicle Accident Costs. [Online]. http://www.fhwa.dot.gov/legsregs/directives/techadvs/t75702.htm. Accessed Jul. 10, 2009.

Flynn, K. M, W. H. Kirby, and P. R. Hummel, 2006. User's Manual for Program PeakFQ, Annual Flood-Frequency Analysis using Bulletin 17B Guidelines. U.S. Geological Survey Techniques and Methods 4-B4.

Gerig, A. J. 1985. Soil Survey of Clackamas County, Oregon. United State Department of Agriculture, Soil Conservation Service, and Forest Service.

Gordon, C., C. Cooper, C. A. Senior, H. Banks, J. M. Gregory, T. C. Johns, J. F. B. Mitchell, and R. A. Wood, 2000. The simulation of SST, sea ice extents and ocean heat transports in a version of the Hadley Centre coupled model without flux adjustments. Climate Dynamics 16:147-168.

Green, G. L. 1983. Soil Survey of Multnomah County, Oregon. United State Department of Agriculture, Soil Conservation Service, and Forest Service.

Green, G. L. 1982. Soil Survey of Washington County, Oregon. United State Department of Agriculture, Soil Conservation Service, and Forest Service.

Hammer, T. 1977. Stream channel enlargement due to urbanization. Water Resources Research 8:1530-1540.

Harrelson, C.C., C. L. Rawlins, and J. P. Potyondy, 1994. Stream channel reference sites: an illustrated guide to field technique. U.S. Department of Agriculture, Forest Service, Rocky Mountain Forest and Range Experiment Station, General Technical Report RM-245, 61p.

Hotchkiss, R.H., E.A. Thiele, E.A., E. J. Nelson, and P.L. Thompson, 2008. Culvert hydraulics comparison of current computer models and recommended improvements. Transportation Research Record 2060: 141-149.

Holman, I. P., M. D. A. Rounsevell, G. Cojacaru, S. Shackley, C. McLachlan, E. Audsley, P. M. Berry, C. Fontaine, P. A. Harrison, C. Henriques, M. Mokrech, R. J. Nicholls, K. R. Pearn \& J. A. Richards. 2008. The concepts and development of a participatory regional integrated assessment tool. Climatic Change, 90: 5-30.

Huntington, T. 2006. Evidence for intensification of the global water cycle: Review and synthesis. Journal of Hydrology 319: 83-95.

Interagency Advisory Committee on Water Data (IACWD) 1982, Guidelines for determining flood-flow frequency: Bulletin 17B of the Hydrology Subcommittee, Office of Water Data Coordination, U.S. Geological Survey, Reston, Va., 183 p., http://water.usgs.gov/osw/bulletin17b/bulletin_17B.html (last accessed 3 June 2009).

ICF. 2008. The potential impacts of global sea level rise on transportation infrastructure. ICF International, Fairfax. http://www.bv.transports.gouv.qc.ca/mono/0965210.pdf (last accessed 12 July 2009).

Intergovernmental Panel on Climate Change (IPCC), 2007. Climate change 2007: the physical science basis. Contribution of Working Group I to the Fourth Assessment Report of the Intergovernmental Panel on Climate Change, Cambridge: Cambridge University Press.

Jacob, K., V. Gornitz, and C. Rosenzweig. 2007. Vulnerability of the New York City Metropolitan Area to Coastal hazards, Including Sea Level Rise - Inferences for Urban Coastal risk management and Adaptation Policies. In Managing Coastal Vulnerability (L. McFadden, R. Nicholls, and e. penning-Roswell, eds). Oxford: Elsevier, pp.141-158.

Kay, A. L., H. N. Davies, V. A. Bell, and R. G. Jones, 2009. Comparison of uncertainty sources for climate change impacts: flood frequency in England. Climatic Change, 92: 41-63. 
Kirshen, P., K. Knee, and M. Ruth, 2008. Climate change and coastal flooding in Metro Boston: impacts and adaptation strategies. Climatic Change 90: 453-473.

Knight, C. G., J. Jäger (eds), 2009. Integrated regional assessment of global climate change. New York: Cambridge University Press.

Koetse, M. J., and P. Rietveld, 2009. The impact of climate change and weather on transport: An overview of empirical findings. Transportation Research Part D-Transport and Environment, 14: 205-221.

Laenen, A. and J. C. Risley, 1997. Precipitation-Runoff and Streamflow Routing Models for the Willamette River Basin, Oregon. USGS Water-Resources Investigation Report 95-4284.

Leavesley, G. H., S. L. Markstrom, P. J. Restrepo, and R. J. Viger, 2002. A modular approach to addressing model design, scale, and parameter estimation issues in distributed hydrological modelling. Hydrological Processes 16(2):173-187.

Leopold, L.B., M.G. Wolman, and J.P. Miller. 1964. Fluvial Processes in Geomorphology. W.H. Freeman and Company, San Francisco, CA.

Lindgreen, J., D. K. Jonsson, A., Carlsson-Kanyama, 2009. Climate adaptation of railways: lessons from Sweden. EJTIR 9(2): 164-181.

Lonergan, S., R. Difrancesco, and M-K. Woo, 1993 Climate change and transportation in Northern Canada: An integrated impact assessment. Climatic Change 24: 331-351.

Mahmassani, H.S. 2001. Dynamic network traffic assignment and simulation methodology for advanced system management applications. Networks and Spatial Economics 1(3): 267-292.

Metro. 2009. Daily vehicle miles of travel (DVMT) for Portland http://www.oregonmetro.gov/index.cfm/go/by.web/id=16340 (last assessed July 7, 2009).

National Research Council (NRC) 2008. Potential Impacts of Climate Change on U.S. Transportation, Transportation Research Board Special Report 290. Washington, DC: National Academies Press.

National Research Council (NRC) 2007. Metropolitan Travel Forecasting: Current Practice and Future Direction, Transportation Research Board Special Report 288. Washington, DC: National Academies Press.

National Research Council (NRC). 1999. The Costs of Natural Disasters: A Framework for Assessment. Washington, DC: National Academy Press.

Oregonian. 2007. Johnson Creek floods, closing nearby roads. http://blog.oregonlive.com/breakingnews/2007/12/johnson_creek_reaches_flood_st.html (last accessed 7, July 2009).

Oregon Climate Service (OCS). 2008. Station Climate Data, Zone 2. http://www.ocs.orst.edu/index.html (last accessed 2 October 2008).

Oregon Department of Transportation. 2009. Estimating Average Bid Item Prices. http://public.oregon.gov/ODOT/HWY/ESTIMATING/bid_item_prices.shtml\#Region_Weighted_Av erage_Prices. Accessed Jul. 20, 2009.

Peeta, S. and A.K. Ziliaskop. 2001. Foundations of dynamic traffic assignment: The past, the present and the future. Networks and Spatial Economics 1(3): 233-265.

Pielke, R. A., and M. W. Downton, 2000. Precipitation and damaging floods: Trends in the United States, 1932-97. Journal of Climate 13: 3625-3637.

Randall, D. A., R. A. Wood, S. Bony, R. Colman, T. Fichefet, J. Fyfe, V. Kattsov, A. Pitman, J. Shukla, J. Srinivasan, R. J. Stouffer, A. Sumi, and K. E. Taylor. 2007. Climate models and their evaluation. In Climate Change 2007: The Physical Science Basis. Contribution of Working Group I to the Fourth Assessment Report of the Intergovernmental Panel on 
Climate Change. Edited by Solomon, S., D. Qin, M. Manning, Z. Chen, M. Marquis, K.B. Averyt, M. Tignor and H.L. Miller. New York: Cambridge University Press. 589-662.

Rosenbrock, H. H. 1960. An automatic method of finding the greatest or least value of a function. Computer Journal 3:175-184.

Salathé E. P., P. W. Mote, and M. W. Wiley. 2007. Review of scenario selection and downscaling methods for the assessment of climate change impacts on hydrology in the United States Pacific Northwest. International Journal of Climatology 27: 1611-1621.

Smith J. 2009. Risk Management Associated With Emergency Vehicle Operation. National Fire Academy, Nov. 1998. [Online]. www.usfa.dhs.gov/pdf/efop/efo29053.PDF. Accessed Jul. 30, 2009.

Sohn, J. 2006. Evaluating the significance of highway network links under the flood damage: An accessibility approach. Transportation Research Part A, 40: 491-506.

Soleckie, W.D., and C. Rosenzweig. 2001. The impact of potential climate change in Metropolitan New York. In From the Hudson to the Hamptons: Snapshots of the New York Metropolitan Area. Editited by I. M. Miyares, M. Pavlovskaya, and G. Pope. Washington DC. Association of American Geographers.

Suarez, P., W. Anderson, V. Mahal, and T. R. Lakshmanan. 2005. Impacts of flooding and climate change on urban transportation: A systemwide performance assessment of the Boston Metro Area. Transportation Research Part D-Transport and Environment 10(3): 231-244.

Transportation Research Board (TRB). 2001. Economic Implications of Congestion. National Cooperative Highway Research Program Report 463. National Research Council. pp. 9-33.

US Army Corps of Engineers, 2010. HEC-RAS River Analysis System: Hydraulic Reference Manual. Davis, CA.

Wagener, T., and H. S. Wheater. 2006. Parameter estimation and regionalization for continuous rainfall-runoff models including uncertainty. Journal of Hydrology 320:132-154.

Washington County. Washington County: Natural hazards mitigation plan. Office of Emergency Management. Jan. 2006. [Online]. http://www.co.washington.or.us/deptmts/cao/mitigate/plan.htm. Accessed Jul. 14, 2009.

Wood, A.W., L.R. Leung, V. Sridhar, D. P. Lettenmaier, 2004. Hydrologic implications of dynamic and statistical approaches to downscaling climate model outputs. Climatic Change 62 (1-3): 189-216.

Wilby, R.L. and I. Harris. 2006. A framework for assessing uncertainties in climate change impacts: Low-flow scenarios for the River Thames, UK. Water Resources Research 42: W02419.

Wurbs, R., S. Toneatti, and J. Sherwin. 2001. Modeling uncertainty in flood studies. International Journal of Water Resources Development 17(3): 353-363. 



\section{GOTREC \\ AND EDUCATION CONSORTIUM}

P.O. Box 751

Portland, OR 97207

OTREC is dedicated to stimulating and conducting collaborative multi-disciplinary research on multi-modal surface transportation issues, educating a diverse array of current practitioners and future leaders in the transportation field, and encouraging implementation of relevant research results. 